d. COLUMBIA | SIPA

Center on Global Economic Governance

CDEP-CGEG WORKING PAPER SERIES

CDEP-CGEG WP No. 8

Does Wealth Inequality Matter for Growth?

The Effect of Billionaire Wealth, Income

Distribution, and Poverty

Sutirtha Bagchi and Jan Svejnar

October 2013

dol COLUMBIA $\mid$ SIPA

Center for Development Economics and Policy 


\title{
Does Wealth Inequality Matter for Growth? The Effect of Billionaire Wealth, Income Distribution, and Poverty*
}

\author{
Sutirtha Bagchi ${ }^{\dagger}$ and Jan Svejnar ${ }^{\ddagger}$
}

October 28, 2013

\begin{abstract}
${ }^{\dagger}$ Stephen M. Ross School of Business, University of Michigan, Ann Arbor, MI, USA. Email: sbagchi@umich.edu ${ }^{\ddagger}$ School of International and Public Affairs, Columbia University, NY, USA and CEPR, IZA, CERGE-EI. Email: js4085@columbia.edu
\end{abstract}

\begin{abstract}
A fundamental question in social sciences relates to the effect of wealth inequality on economic growth. Yet, in tackling the question, researchers have had to use income as a proxy for wealth. We derive a global measure of wealth inequality from Forbes magazine's listing of billionaires and compare its effect on growth to the effects of income inequality and poverty. We find that wealth inequality reduces economic growth, but when we control for the fact that some billionaires acquired wealth through political connections, the effect of politically connected wealth inequality is negative, while politically unconnected wealth inequality, income inequality, and initial poverty have no significant effect.
\end{abstract}

JEL codes: D31 (Distribution - Personal Income and Wealth Distribution), O40 (Economic Growth and Aggregate Productivity - General), O43 ((Economic Growth and Aggregate Productivity - Institutions and Growth).

Key words: Economic Growth; Wealth Inequality; Income Inequality, Billionaires, Political Connections.

${ }^{*}$ We thank (without implicating) Lakshmi Iyer, Scott Masten, Jagadeesh Sivadasan, Joel Slemrod, Dmitriy Stolyarov, and Dietrich Vollrath for helpful comments. We also thank seminar participants at Harvard Business School, Hong Kong University of Science and Technology, London Business School, the Midwest Economic Association Annual Conference, the Eastern Economic Association Annual Conference, University of Michigan, and Wesleyan University for helpful comments. 


\section{Introduction}

A central question in the social sciences is whether inequality in control over a society's resources facilitates or hinders economic growth. Although there is a large theoretical and empirical literature on this topic, the question is far from settled.

Three important features of the literature contribute to this lack of consensus. First, although theoretical arguments are usually based on the distribution of wealth, nearly all empirical studies use the distribution of income rather than wealth because data on the distribution of wealth do not exist for a sufficient number of countries. As Aghion, Caroli and Garcia-Penalosa (1999: pp. 1617-18) explain, “. . . the absence of data on the distribution of wealth for a sufficient number of countries forces researchers to use proxies in empirical studies. The most common approach is to use data on income inequality as a proxy for wealth inequality." Bénabou (1996) echoes this point when he notes that the lack of almost any data on the distribution of wealth is a general problem, given that in most theories it is this distribution rather than that of income which is the determinant of outcomes. Finally, while discussing studies that use income inequality, Ravallion (2012: p. 506) emphasizes that "wealth inequality is arguably more relevant though this has been rarely used due to data limitations."

Second, the literature does not adequately account for the sources of inequality. Consider Indonesia and United Kingdom. Although these countries appear similar on measures of income inequality, their respective Gini coefficients being 32.5 and 33.7, they differ markedly on such dimensions as the role that political connections have played in achieving economic success and bringing about their distribution of income and wealth. Yet, virtually all empirical studies ignore this distinction and examine the effects of aggregate measures of inequality on economic growth. ${ }^{2}$

Third, in an important multi-country study, Ravallion (2012) has recently cast serious doubt on inequality as a determinant of growth, suggesting that it is initial poverty rather than income inequality that affects economic growth of countries.

In this paper, we address the shortcomings noted in the first two points above and we provide new evidence on the third point, namely the issue of whether inequality or poverty affects growth. We first develop a measure of wealth inequality based on Forbes magazine's annual world-wide listing of billionaires. Second, we introduce two new variables reflecting the extent, if any, to which billionaire wealth has been obtained through political connections (cronyism). We next use annual data for 1987-2007 to construct four five-year panels and test hypotheses regarding the effects on growth of our overall measure of wealth inequality, our measures of politically connected and unconnected wealth inequality, income inequality, and poverty. To the best of our knowledge, ours is the first paper to examine the effect of wealth inequality on

\footnotetext{
${ }^{1}$ The only study that directly uses wealth inequality data and looks at the effect of wealth inequality on growth is a paper by Ravallion (1998) who studies the effect of geographic differences in the distribution of wealth on growth in China and finds evidence that high wealth inequality impedes growth.

${ }^{2}$ Easterly (2007) is a notable exception in that he distinguishes between structural and market-based inequality. A fuller discussion of the relationship between his paper and our work is provided in sections 2 and 4 below. Moreover, as we discuss below, Morck, Stangeland, and Yeung (2000) note that when they divide billionaires into those who were self-made versus those who inherited their wealth, a country's per capita GDP grows faster if its self-made billionaire wealth is larger as a fraction of GDP and slower if inherited billionaire wealth is larger as a fraction of GDP.
} 
economic growth in a cross-country, panel data setting, and also the first study to estimate an encompassing model that compares the effects on growth of wealth inequality, income inequality, and poverty. ${ }^{3}$

We also tackle a methodological criticism of much of the literature in this area, namely that findings may be biased on account of endogeneity of inequality in the growth regressions. We follow one of the leading empirical studies in this area - Forbes (2000) - and estimate a fixed effects model with lagged values of the explanatory variables. In addition, while finding valid instruments for traditional instrumental variable (IV) estimation is very difficult in this setting, we also discuss estimates based on two time-varying IVs for wealth inequality.

Our first finding is that wealth inequality has a negative, statistically significant effect on economic growth, while the effect of income inequality is insignificant or only borderline significant, and the effect of poverty is statistically insignificant in all specifications. Hence, using an encompassing model, we show that in the head-on comparison it is wealth inequality, rather than income inequality or poverty that has a significant effect on economic growth.

Our second set of results comes from specifications in which we control for the fact that some billionaires acquired wealth through the use of political connections or cronyism, while others obtained it in a relatively standard legal environment. This estimation is based on a categorization of billionaires that is somewhat subjective. ${ }^{4}$ We are conservative about classifying someone as being politically connected and are also fully up-front about how we carry out the classification. Using the classification, we find that the effect of politically connected wealth inequality on growth is negative, while the effects of politically unconnected wealth inequality, income inequality, and initial poverty are statistically insignificant. The second set of results hence suggests that one needs to pay attention to the sources and nature of wealth inequality.

Our third set of results shows that our estimates are robust to a number of alternative specifications and explores the reason why our results with respect to income inequality differ from those of Forbes (2000) and those with respect to poverty from those of Ravallion (2012).

The structure of the paper is as follows. In Section 2, we offer a brief review of the theoretical and empirical literature that examines the impact of inequality and poverty on growth. In section 3 , we present our empirical strategy and describe the data set used. In Section 4, we validate the use of the inequality variables constructed from Forbes magazine's annual listing of billionaires as reasonable measures of wealth inequality and the importance of political connections in a country's socioeconomic system. In section 5 , we present the main results capturing the impact of wealth inequality (and its components), income inequality, and poverty on growth. We also report a number of robustness checks that show that our findings are robust. Section 6 offers concluding remarks and outlines potential avenues for future work.

\footnotetext{
${ }^{3}$ As we discuss below, a pioneering study by Alesina and Rodrik (1994) and an important later study by Deininger and Olinto (2000) use land inequality as a proxy for wealth inequality, but this measure is more appropriate for low income agrarian societies than the world as a whole.

${ }^{4}$ This is in the same vein as the Corruption scores of the International Country Risk Guide (ICRG) of the University of Maryland, Transparency International's Corruption Perceptions Index, and Fisman's classification scheme (2001) which are also based on perceptions rather than on objective data.
} 


\section{Review of the existing literature}

The early view espoused by Kuznets $(1955)$ and Kaldor $(1956,1961)$ was that economic development affects income distribution, with growth increasing income inequality in the first stages of economic development and reducing it later (the 'inverted-U hypothesis'). Kuznets' hypothesis has been extensively tested and generally has been found to lack empirical support (see, e.g., Fields, 2001 for a review).

In the more recent literature on growth and development the causation between inequality and growth runs in the opposite direction. ${ }^{5}$ The focus is on the effect of wealth inequality and to a lesser extent income inequality on economic growth, with the theoretical literature yielding two main strands of studies. The first strand suggests various transmission mechanisms through which greater initial inequality fosters economic growth. Prominent among them is a higher savings propensity of the rich (Bourguignon, 1981) and investment indivisibilities (Attanasio and Binelli, 2003). The other strand identifies economic and political channels through which inequality may be harmful for growth. These include redistributive taxation that would be favored by the median voter and which would reduce incentives and hence also growth (Meltzer and Richard, 1981; Alesina and Rodrik, 1994; Barro, 1999), credit constraints generated by low levels of collateral by the poor (Galor and Zeira, 1993), sociopolitical instability stemming from the sense of relative deprivation by the poor (Gupta, 1990), and increased fertility among the poor who cannot afford to provide human capital to their children (De La Croix and Doepke, 2003). The idea common to many of these conceptual frameworks that expect a negative effect of wealth inequality on growth is that extreme wealth concentration distorts economic policies and therefore leads to poor economic performance.

As mentioned earlier, the absence of data on the distribution of wealth for a sufficient number of countries has led empirical researchers to rely on alternatives, typically by using data on income inequality as a proxy for wealth inequality. Two partial exceptions are a pioneering study by Alesina and Rodrik (1994) and an important later study by Deininger and Olinto (2000) that use land holdings as a measure of wealth inequality. However, as Alesina and Rodrik (1994) note, land is only one component of wealth and moreover, land does not exactly fit their model's notion of capital as an accumulating asset. In addition, while inequality in land holding may be appropriate for poor agrarian economies, it is not an adequate proxy for wealth inequality in more developed economies. ${ }^{6}$ In addition, our calculations based on the 26 countries for which data exist indicate that there is no correlation between the Gini coefficient for land (sourced from Deininger and Olinto (2000)) and Gini coefficient for wealth, nor do we find a correlation between the 20 countries for which we have data on the Gini coefficient for land and the share of wealth going to the top decile of the population of a country. ${ }^{7}$ In contrast, our measure of billionaire wealth normalized by GDP is positively correlated with the Gini coefficient for wealth and the share of wealth going to the top decile.

\footnotetext{
${ }^{5} \mathrm{~A}$ review of this literature may be found in Aghion, Caroli, and García-Peñalosa (1999), Ehrhart (2009), and Galor (2009).

${ }^{6}$ As a study of income tax returns by Bakija et al. (2012) suggests, professionals account for an overwhelming share of the top 1 percent of income earners in the U.S.: 31 percent started or manage nonfinancial businesses, about 16 percent are doctors, 14 percent are a part of the financial services industry, 8 percent are lawyers, 5 percent are scientists and engineers, and about 2 percent are a part of the sports, entertainment or media industries. It would be hard to argue that for such individuals, their holdings of land capture, to any reasonable degree, their asset holdings.

${ }^{7}$ Both measures of wealth inequality are sourced from Davies et al. (2008).
} 
Interestingly, as Davies et al. (2008) point out, "in all countries which have the requisite data, wealth distribution is more unequal than income." This raises the question as to whether the estimated effect of income inequality on growth truly captures the impact of wealth inequality on growth and it provides one motivation for our study.

The empirical literature dealing with income inequality and economic growth is based on crosscountry regressions and, more recently, on panel data analysis. While cross-country regressions examine the long-run relationship and generally find a negative impact of income inequality on growth (see e.g., Alesina and Rodrik, 1994, Persson and Tabellini, 1994, and Perotti, 1996), panel data estimates aim at measuring the short and medium-term relationship and they obtain mixed evidence (see e.g., Forbes, 2000 and Barro, 2000).

A possible reconciliation of the opposing views on whether inequality has a positive or negative impact on growth is made by Easterly (2007: 756) who notes:

One confusion in the theoretical and empirical analysis of inequality is between what we could call structural inequality and market inequality. Structural inequality reflects such historical events as conquest, colonization, slavery, and land distribution by the state or colonial power; it creates an elite by means of these non-market mechanisms. Market forces also lead to inequality, but just because success in free markets is always very uneven across different individuals, cities, regions, firms, and industries. So the recent rise in inequality in China is clearly market-based, while high inequality in Brazil or South Africa is just as clearly structural. Only structural inequality is unambiguously bad for subsequent development in theory; market inequality has ambiguous effects - it could have some of the adverse effects cited in the above models, but eliminating it would obviously have negative incentive effects.

As we discuss later, our first step toward quantifying the importance of political connections goes in the direction of operationalizing Easterly's notion of structural inequality.

Finally, an important motivation for our study comes from Morck, Stangeland, and Yeung (2000) who find that when they divide the world's billionaires into those who were self-made versus those who inherited their wealth, a country's per capita GDP grows faster if its self-made billionaire wealth is larger as a fraction of GDP and slower if inherited billionaire wealth is larger as a fraction of GDP. They argue that the deleterious consequences of having the very wealthy control a very large fraction of a country's assets can lead to entrenchment, bias capital allocation, retard capital market development, obstruct entry by outsider entrepreneurs, and cumulatively retard economic growth. These observations lead Morck, Wolfenzon, and Yeung (2005) to speculate that "inequality involving new money wealth seems different from inequality involving old money wealth." They suggest that "economists need to think less about concentration of wealth per se and more about concentration of wealth in whose hands."

We use this finding as our point of departure in analyzing the relatively unexplored area of the effect of different sources and nature of wealth inequality on growth. In particular, many countries that generated low rates of economic growth were also characterized by a high level of wealth concentration among entrenched elites, frequently politicians and their cronies. The negative correlation between inequality and 
growth in a cross-section of countries could thus have more to do with the fact that a large share of the national wealth is held by a small number of politically connected families than with higher tax rates or higher expenditure on transfers and subsidies, which are among the channels through which inequality is often believed to affect growth.

The literature on the effect of poverty v. income inequality on economic growth is represented by an important contribution by Ravallion (2012) who uses country-level data based on household surveys to examine the effect of initial poverty and income distribution on subsequent economic growth. His dataset covers 90 countries with two surveys at varying points in time, and most of the estimation is hence carried out in a cross-sectional setting. For about two-thirds of the countries, there are three or more surveys and these countries are used for robustness checks, including the GMM estimation and allowing for country fixed effects. Ravallion's (2012) key cross-sectional result, obtained in an OLS model, is that poverty rather than income inequality affects growth and that the effect of poverty on growth is negative. Moreover, he finds that this result holds in the GMM model but vanishes in the specification with country fixed effects.

\section{Data and Empirical Approach}

\subsection{Construction of data on Wealth Inequality}

The key new source of data that we use is Forbes magazine's annual listing of billionaires. Although Forbes has been publishing a list of the four hundred richest Americans since 1982, it was only in 1987 that it expanded its coverage to the richest individuals and families around the world. ${ }^{8}$ We use this latter list and assign each billionaire to a country based on the locus of his business activities, which often coincides with his location. We generate three measures of wealth inequality defined for each year as the sum of the wealth of all the billionaires in a given country divided by either the country's GDP or physical capital stock or population. ${ }^{9}$ Our first measure parallels that reported by The Economist (2012) for several countries and in section 4.1 we show that our three measures are correlated with other measures of wealth inequality.

Because of the nature of construction of our wealth inequality variables, we focus on the effects of concentration of wealth at the top of the wealth distribution pyramid. Our paper hence belongs to the class of studies that examine inequality via the concentration of wealth or income in the top quantiles rather than taking into account the entire distribution (e.g., Davies et al., 2008, Piketty and Saez, 2003 and 2010, and Wolff, 2006). Focusing on the top of the distribution is useful because over the last several decades concentration of income and wealth at the top has increased (e.g., Piketty and Saez, 2003, and The Economist, 2012). It is also widely believed that this concentration affects economic and social outcomes (e.g., Stiglitz, 2012), and in a number of countries, including the United States and France, government tax policies have been focused on this group. Finally, as Voitchovsky (2012) notes, inequality in different parts

\footnotetext{
${ }^{8}$ The list of countries that appear on the Forbes' billionaire list in each year is provided in the Data Appendix A.2.

${ }^{9}$ As billionaire wealth, GDP, and physical capital stock are expressed in nominal terms, the ratio of billionaire wealth to GDP or billionaire wealth to physical capital stock should not exhibit any secular trends because of inflation.
} 
of the income distribution has different effects on growth and a single inequality statistic for the entire distribution is insufficient to capture the effects of inequality on growth. Our results may therefore be seen as reflecting the impact on growth of wealth inequality at the top of the distribution.

The second prong of our analysis focuses on examining the prediction that the effect of wealth inequality on growth depends on whether wealth has been acquired through political connections. We identify the fraction of billionaire wealth that has been generated through the use of political connections by classifying each billionaire into one of two categories: those who benefited from political connections and those who did not. We start by creating a dummy variable called "Political connections" and set it equal to 1 when we conclude through an extensive search on Factiva and LexisNexis using news sources from around the world that political connections had a material part to play in the success of the billionaire. We set this variable equal to 0 when we conclude that political connections have not been crucial to the billionaire's rise to riches even though he may have had prior political connections. The criterion we use for classifying billionaires as having benefited from political connections is that our extensive review of evidence indicates that the person would not have become a billionaire in the absence of political connections that resulted in favoritism and/or explicit government support. ${ }^{10}$ Three examples of billionaires who are classified as politically connected are provided in the Data Appendix A.3. A full classification of billionaires into the two categories of politically connected and politically unconnected is available from the authors on request.

As our discussion indicates, our measure is conservative in that only individuals who quite clearly benefited from political connections as a means of becoming billionaires are included in the politically connected category. In fact, in classifying billionaires into the two categories, we distinguish between altering the playing field to benefit a particular individual or group of individuals from a generally pro-business regulatory environment. Thus for instance in Hong Kong or Singapore, all businessmen and entrepreneurs benefit from the pro-business administrations. ${ }^{11}$ This is different from the case of, say, Indonesia, where during the Suharto regime it really mattered whether one knew Suharto because that could make all the difference between obtaining a potentially lucrative import license or not (Mobarak and Purbasari, 2005). Or consider the case of Russia, which did not have a single billionaire until 1996, when we observe a sudden spurt in their number on account of the large-scale privatization of state assets that took place as part of Boris Yeltsin's re-election as President. In these cases, after the review of news sources from around the world, we conclude that these individuals profited from ties to politicians and would not have been billionaires without their support. Only in such cases do we classify billionaires as politically connected. In our sample, politically connected billionaires account for anywhere between $4 \%$ and $13 \%$ of total billionaire wealth, depending on the year under consideration. ${ }^{12}$

It turns out that countries where entrenched elites control a large fraction of the country's resources

\footnotetext{
${ }^{10}$ We classify a billionaire as politically connected if either the person who originated the wealth benefited from political connections or if the person who was growing the wealth benefited from political connections.

${ }^{11}$ In the 2011 Annual Report of Economic Freedom of the World (Gwartney, Hall, and, Lawson, 2011), Hong Kong and Singapore enjoy the highest rating for economic freedom, a distinction they have held in every single year the report was generated since 1990 (pp. 82 and 141).

${ }^{12} \mathrm{By}$ this measure, the countries with the highest level of politically connected wealth inequality are Malaysia, Colombia, Indonesia, Thailand, and Mexico.
} 
are also likely to be countries where a large fraction of billionaires have reached their status through the reliance on such political connections. In Section 4.2, we offer evidence that our measure of politically connected billionaire wealth is a reasonable proxy for the importance of political connections in a country by showing that it is highly correlated with two widely used measures of corruption and an instrument developed in Easterly (2007).

Overall, while our classification of billionaires into politically connected and politically unconnected may be viewed as being subjective, we note that the two most widely-used measures of corruption (the Corruption scores of the International Country Risk Guide (ICRG) of the University of Maryland and Transparency International's Corruption Perceptions Index) are also based on perceptions rather than on objective data. ${ }^{13}$ Perception is also at the heart of the classification scheme employed by Fisman (2001) in that his measure of the importance of political connections to firms in Indonesia is based on "the subjective assessments of a number of top consultants." 14 Finally, we reiterate that our primary finding - the effect of wealth inequality on economic growth - is independent of our classification of billionaires into politically connected or unconnected.

Our panel begins in 1987, the first year in which the Forbes magazine's list of billionaires from around the world was published. Replicating the 5-year panel structure in Forbes (2000) implies using lists from years 1987, 1992, 1997, and 2002. We do so, but because Forbes magazine changed its editorial criteria for inclusion in its billionaire list for the period 1997 to 2000, we substitute billionaire information from 1996 for 1997. Further details regarding the construction of the wealth inequality variable and the robustness of results to using the 1997 list instead of the 1996 list are provided in the Data Appendix A.1.

The unit of observation in our sample is a country-(5 year) period combination. We supplement the sample that corresponds to the data from the Forbes magazine with countries that do not have billionaires but for which data on all other variables are available. We use these countries in our base regressions and assign them a value of zero for billionaire wealth inequality and its components. Assigning a value of zero is reasonable given the comprehensive nature of Forbes magazine's coverage of billionaires. The inclusion of these additional countries brings the number of country-period observations to 395, of which 269 correspond to the absence of any billionaires and 126 correspond to the presence of billionaires. ${ }^{15}$ Summary statistics for the Forbes' billionaire data for these 126 country-period observations are provided in Table 1.

[Table 1 about here.]

As may be seen from the Table, the number of countries on the Forbes' list grows over time. While only 23 countries appear on the first list in 1987, 41 countries appear on the list by 2002 . The average

\footnotetext{
${ }^{13}$ Transparency International describes it thus: "There is no meaningful way to assess absolute levels of corruption in countries or territories on the basis of hard empirical data. Capturing perceptions of corruption of those in a position to offer assessments of public sector corruption is the most reliable method of comparing relative corruption levels across countries."

${ }^{14}$ Of the individuals that Fisman (2001) rates as having the highest level of political connections in Indonesia, two (Liem Sioe Liong and Prajogo Pangestu) show up on the billionaire lists. In both cases, we also independently classify these individuals as politically connected based on our research using Factiva and LexisNexis.

${ }^{15}$ We lose 8 of the 134 country-period observations which have billionaires in the estimation because data on schooling is not available for these observations. These correspond to Saudi Arabia (all 4 years: 1987, 1992, 1996, and 2002), Liechtenstein (1996 and 2002 ), Russia (2002), and United Arab Emirates (2002).
} 
level of wealth inequality in these countries, calculated as the sum of all billionaire wealth in the country normalized by GDP, varies between a low of 3.5\% in 1987 and 1992 to a high of $7.6 \%$ in 1996. A list of countries which appear in the billionaire lists in each year of the sample is provided in Data Appendix A.2.

For income inequality we use data from the second round of the World Income Inequality Database compiled by the UNU - WIDER project on "Global Trends in Inequality and Poverty". This is the most recent data set on income inequality and it provides data on various measures of income inequality for over 150 countries with most observations drawn from the period between 1970 and 2006 . We exclude from the data set all observations that do not cover an entire country or an entire population. Within the subset of surveys that meet our criteria, some inequality measures are based on the household, whereas others are based on the individual. Similarly, some inequality measures are based on income, while others are based on expenditure (or consumption). Given that the Gini coefficient is the most commonly available income inequality measure in the Database (and also the one used in the key study by Forbes, 2000), we use it instead of other possible measures.

Finally, for initial poverty we use the headcount index $\left(H_{i t}\right)$, given by the proportion of the population living in households with consumption per capita (or income when consumption is not available) below the poverty line and sourced from the World Bank's PovcalNet tool. Following Ravallion (2012), the poverty line is set at $\$ 2$ per person per day at $2005 \mathrm{PPP}$, which is the median poverty line amongst developing countries. For robustness, we also consider a lower line of $\$ 1.25$ a day which is the expected value of the poverty line in the poorest countries in terms of consumption per person and obtain similar results as those obtained with the $\$ 2$ per person per day definition.

\subsection{Empirical Approach}

The literature on the effects of income inequality and growth has generated concerns that cross-country, cross-sectional regressions lead to omitted variable bias (Forbes, 2000) and non-robustness of results (Levine and Renelt, 1992, and Deininger and Squire, 1998). To overcome these concerns, we use panel data to examine the effects on growth of wealth inequality, income inequality, and poverty. We start by using a fixed effects specification that is similar to Forbes (2000), with the difference being that we use wealth distribution, income distribution, and poverty (rather than just income distribution) as our key regressors of interest. As in Forbes (2000), we regress the real GDP growth rate per capita in a five-year period $t$ on the values of the explanatory variables at the end of period t-1 (i.e., in the year preceding the start of the five-year period $t$ ). The literature has maintained that in a fixed effects model the values of the lagged variables may be viewed as being predetermined and therefore unlikely to suffer from problems related to reverse causality (endogeneity). Hence, the initial specification we use is: 


$$
\begin{gathered}
\text { Growt }_{i, t}=\beta_{0}+\beta_{1} \text { Wealth inequality }_{i,(t-1)}+\beta_{2} \text { Income inequality }_{i,(t-1)}+\beta_{3} \text { HeadcountPoverty }_{i,(t-1)}+ \\
\beta_{4} \text { Income }_{i,(t-1)}+\beta_{5} \text { Schooling }_{i,(t-1)}+\beta_{6} \text { PPPI }_{i,(t-1)}+\beta_{7} \text { Dummy }_{i,(t-1)}+\alpha_{i}+\eta_{t}+\nu_{i, t}
\end{gathered}
$$

where $i$ denotes country and $t$ annual time period (with $t=1,2, \ldots \mathrm{T}$ ). Growth is measured as the average annual growth rate in real GDP per capita in country $i$ in period $t$, while wealth inequality, income inequality, and headcount poverty have been defined above. "Income" is the real GDP per capita. "Schooling" is the average years of secondary schooling in the male and female populations aged 25 and above, and PPPI is the value of the investment deflator, used as a proxy for market distortions. "Dummy" is set to 1 for all country-period observations which have at least one billionaire and 0 for countries which do not. Country fixed effects $\alpha_{i}$ are incorporated to account for time-invariant country idiosyncratic factors, while period fixed effects $\eta_{t}$ control for global shocks in each period that are common across countries. Finally, $\nu_{i, t}$ is the random error term. Throughout the paper, we cluster standard errors at the country level, thus allowing arbitrary country-specific serial correlation. This is arguably the most conservative way of dealing with the problem of serial auto correlation (Bertrand, Duflo, and Mullainathan, 2004).

As mentioned above, the key new explanatory variable, wealth inequality, is constructed as total billionaire wealth normalized by the country's GDP or physical capital stock or population. The choice of these variables for normalizing is based on the fact that data on the total wealth holdings in each country, the preferred denominator, is unavailable. At the same time, it is essential to normalize the raw billionaire wealth holdings by a measure of the size of a given economy since not doing so would lead to artificially inflated values of wealth inequality for countries with a high per capita income and a large population. Thus, absent measures of wealth holdings for each country, we use GDP, physical capital stock, and population as alternatives for normalizing billionaire wealth. ${ }^{16}$ When using a country's physical capital stock, we generate values of the physical stock of a country by the perpetual-inventory method (Nehru and Dhareshwar, 1993) and re-define wealth inequality as the ratio of the sum of billionaire wealth for a given country in a given year to the total estimated physical stock of capital in that country in that year. ${ }^{17}$ As we show later, using GDP, physical capital stock, and population for normalizing billionaire wealth yield mostly similar results.

Since not all countries included in the estimation have billionaires in any given year, we control for this feature by introducing a dummy variable that takes the value of 1 if a country had billionaires in a given year and 0 if it did not. Incorporating this dummy variable into the regression allows countryyear observations without billionaires to have different fixed effects than countries with billionaires in any given period. Furthermore, including countries without billionaires allows us to estimate more precisely the effects of the other variables on economic growth.

As mentioned earlier, we develop a proxy variable for the importance of political connections based

\footnotetext{
${ }^{16}$ Morck, Stangeland, and Yeung (2000) also use a similar measure in their paper and mention the lack of wealth-based Gini coefficients as an obstacle to estimating the effect of inequality in wealth distribution on economic growth.

${ }^{17}$ We use the Stata module, Stockcapit (Amadou, 2011) for this exercise.
} 
on a classification of whether political connections had a material role in the success of a given billionaire. We then add up the total wealth of all such politically connected billionaires, normalize the sum by the country's GDP or physical capital stock or population, and call the resulting variable "Politically connected wealth inequality." For the billionaires that did not materially benefit from political connections we add up their total wealth, normalize the sum by the country's GDP or physical capital stock or population and label the variable "Politically unconnected wealth inequality." Thus:

Billionaire wealth $/ G D P=$ Politically unconnected billionaire wealth $/ G D P+$

Politically connected billionaire wealth/GDP

Equivalently,

Wealth Inequality $=$ Politically unconnected wealth inequality + Politically connected wealth inequality

and analogously for normalization by physical capital stock and population.

The other variables used in specification (1) are relatively standard in the inequality-growth literature. The dependent variable, growth rate in real GDP per capita, is calculated as the average annual compounded growth rate over a 5-year period of Gross Domestic Product per capita in constant prices and expressed in national currency (IMF, 2009). ${ }^{18}$ Initial income at the start of each period is measured by the log of real GDP per capita in International dollars in 2000 Constant Prices from the Penn World Tables v6.2. Schooling is measured as the average years of secondary schooling in the male and female population aged 25 and above (Barro and Lee, 2001). Because data on schooling are unavailable for years 1987, 1992, 1997, and 2002, data from 1985, 1990, 1995, and 2000 are used instead. Finally, PPPI, the Price Level of Investment is calculated by dividing the purchasing power parity (PPP) for investment goods by the US dollar exchange rate. It is used commonly as a proxy for market distortion that affects the cost of investment, such as tariffs, government regulations, corruption, and the cost of foreign exchange. This variable is common in growth regressions and it is also drawn from the Penn World Tables. ${ }^{19}$ In addition, we include as key explanatory variables, initial poverty and headcount poverty, defined above. Summary statistics for the dependent variable and the explanatory variables for the sample included in the estimation sample are presented in Table 2.

\section{[Table 2 about here.]}

Overall, three considerations have affected our choice of regressors in the basic specification: (i) comparability with the existing literature, (ii) need for parsimony, and (iii) possible endogeneity of some control variables that are typically used in standard growth equations, such as government expenditure and proxies for political and institutional instability (Perotti, 1996; Forbes, 2000).

\footnotetext{
${ }^{18}$ Sourced from:http://www.imf.org/external/pubs/ft/weo/2009/01/weodata/index.aspx.

${ }^{19}$ Initial income and PPPI are obtained from the Penn World Tables (http://pwt.econ.upenn.edu/php_site/pwt62/pwt62_form.php). PPPI is frequently used in the macroeconomic and international literature and measures how the cost of investment varies between each country and the United States.
} 


\section{The Validity of Billionaire Wealth as a Measure of Inequality}

In Section 3.1 we have described the nature of our measures of wealth inequality and provided justification for focusing on the top of the wealth distribution pyramid. In this section we provide additional information about the validity of our measures. ${ }^{20}$

\subsection{Wealth Inequality}

To assess further whether normalized billionaire wealth is a useful proxy for wealth inequality, we compare our measure with data on wealth inequality reported by Davies et al. (2008). These authors provide crosssectional data on the share of wealth that is held by the top decile of the population (and the Gini coefficient of wealth) for a set of 20 (26) countries, respectively, of which 18 (22) have billionaires in at least one of the four years of our sample (1987, 1992, 1996, and 2002). Comparisons of our billionaire wealth measure normalized by GDP with the closest-year values of the Davies et al. (2008) measures are reported in Table 3.

[Table 3 about here.]

The raw correlation coefficient and Spearman rank correlation coefficient for the share of wealth going to the top decile and the measure of wealth inequality that we construct (Panel A) for a sample of 18 countries are 0.54 (p-value $=0.0199)$ and 0.58 ( $\mathrm{p}$-value $=0.0122)$, respectively. Examining the crosscountry correlation between the Gini coefficients of wealth available for 22 countries for the year 2000 from the Davies et al. (2008) data set and the measure of wealth inequality for 2002 constructed in this paper (Panel B) shows a positive and statistically significant correlation of 0.50 at the $2 \%$ level $(p=0.0188)$. These positive correlations suggest that our measure of wealth inequality is reasonable.

Our data also reflect the general pattern of increasing inequality around the world that has been noted, among others, by Smeeding (2005), Brandolini and Smeeding (2009), Galbraith (2009), and The Economist (2012). For example, we find that in 8 of the 22 countries that have billionaires in each of the four years of our sample, wealth inequality, as measured by us, increases monotonically over time. This increase in inequality comes from the combined effect of an increase in the number of billionaires for each country, and a general trend of increasing average billionaire wealth for each country. Representative data from three such countries - France, Germany, and Italy - are shown in Figure 1.

[Figure 1 about here.]

In addition, if we compare the level of inequality in 1987, the starting period of our sample, with that in 2002, the last year of our sample, we find that wealth inequality increased in 17 of the 23 countries during

\footnotetext{
${ }^{20}$ In this section, in the interest of brevity, we only include results when billionaire wealth is normalized by GDP. Results when billionaire wealth is normalized by physical capital stock or population are similar and are available on request. In addition, we note that billionaire wealth, normalized by GDP and billionaire wealth, normalized by physical capital stock are correlated with a correlation coefficient of $0.9552(\mathrm{p}<0.001)$ and billionaire wealth, normalized by GDP and billionaire wealth, normalized by population are correlated with a correlation coefficient of $0.8085(\mathrm{p}<0.001)$.
} 
this period and declined in only 6 of them. To arrive at a similar measure for the global economy, we look at the same set of countries that have billionaires and limit ourselves to those for which data is available on all the control variables. We add up the total billionaire wealth of all these countries and normalize that by the sum of their GDPs to arrive at a measure of global wealth inequality. Such a measure of global wealth inequality more than doubles for the entire world during this period, starting from a relatively low value of $2.3 \%$ in 1987 and culminating in a value of $5.2 \%$ in 2002 . This rise can be decomposed into a rise in the number of billionaires (or billionaire families) on the list from 167 in 1987 to 495 in 2002, and a rise in the average wealth per billionaire from $\$ 2.16$ billion in 1987 to $\$ 3.46$ billion in 2002 . Based on these pieces of evidence, we feel that billionaire wealth, normalized by country GDP, physical capital or population, can serve as a reasonable proxy of wealth inequality for a country - measured as concentration of wealth at the top of the distribution.

\subsection{Validity of Politically Connected Wealth Inequality}

To assess whether politically connected billionaire wealth is a reasonable proxy for the importance of political connections and cronyism in a country, we examine the extent to which this measure accords with other proxies such as the extent of corruption in a society. One source of data on corruption is the aforementioned ICRG. Data on corruption in government are available on an annual basis for 100 to 140 countries (depending on the year) from 1984 through $2009 .{ }^{21}$ It thus overlaps with the four years in our sample. We examine the relationship between politically connected wealth inequality and the ICRG Corruption score for all countries that have billionaires using specification (3a) for each individual year and using (3b) when pooling data across all years:

$$
\begin{gathered}
\text { Politically connected wealth inequality } y_{i}=\gamma_{0}+\gamma_{1} * \text { ICRG Corruption } \text { Score }_{i}+\nu_{i} \\
\text { Politically connected wealth inequality } y_{i, t}=\delta_{0}+\delta_{1} * \text { ICRG Corruption Score } \text { S }_{i, t}+\eta_{t}+\nu_{i, t}
\end{gathered}
$$

where $\nu_{i}$ and $\nu_{i, t}$ are the random error terms in (3a) and (3b), respectively, and $\eta_{t}$ in (3b) represent a set of period dummies. Results from estimating specification (3a) are reported in columns (1) through (4) of Panel A in Table 4. Results from estimating (3b) using a pooled OLS approach and a random effects specification are presented, respectively, in columns (5) and (6) of Panel A. The same exercise is repeated in panels B and C, using politically unconnected wealth inequality in Panel B and wealth inequality in Panel C.

\section{[Table 4 about here.]}

The coefficient in the first row of Panel A of Table 4 suggests that our measure of politically connected

\footnotetext{
${ }^{21}$ Lower scores indicate "high government officials are likely to demand special payments" and that "illegal payments are generally expected throughout lower levels of government" in the form of "bribes connected with import and export licenses, exchange controls, tax assessment, police protection, or loans." The measure ranges in value from 0 to 6 , with higher values indicating less corruption. In order to have a higher score correspond to a higher rather than lower level of corruption and also have it range from 0 to 1 , we rescale the measure accordingly.
} 
wealth inequality and the ICRG index of corruption are strongly and positively correlated with each other. Countries that are more corrupt are countries that have a higher fraction of society's resources controlled by politically connected billionaires. In contrast, politically unconnected billionaire wealth normalized by GDP (Panel B) and billionaire wealth normalized by GDP (Panel C) are not significantly correlated with the ICRG Corruption scores. If anything, the negative and statistically significant coefficients in columns (1) and (5) of Panel B of the table suggest that countries that are less corrupt are countries where a higher fraction of society's resources is controlled by billionaires who did not benefit materially from political connections.

We also note that for the five countries with the highest level of politically connected wealth inequality (Malaysia, Colombia, Indonesia, Thailand, and Mexico), the median ranking on the Transparency International's Corruption Perceptions Index ${ }^{22}$ was 32 (out of 41 countries) in 1995 and 94 (out of 174 countries) in 2012. In contrast, for the six countries that had billionaires in every year of the sample and yet had no politically connected billionaires in any year (Hong Kong, Netherlands, Singapore, Sweden, Switzerland, and United Kingdom), the median ranking on the Corruption Perceptions Index was 9 (out of 41 countries) in 1995 and 8 (out of 174 countries) in 2012. ${ }^{23}$ This also suggests the reasonableness of our classification scheme for billionaires as politically connected and politically unconnected.

Finally, in addition to the regressions presented in Table 4, we have also calculated simple univariate correlations between an IV developed in Easterly (2007) and our measure of political connectedness. Easterly's instrument builds on a body of work by Engerman and Sokoloff (Engerman and Sokoloff, 1997 and Sokoloff and Engerman, 2000) (henceforth ES). ES suggest that factor endowments are a central determinant of inequality, which Easterly (2007: 756) refers to as structural inequality and contends that:

... structural inequality in turn is a determinant of bad institutions, low human capital investment, and underdevelopment. ES argues that the land endowments of Latin America lent themselves to commodities featuring economies of scale and the use of slave labor (sugar cane is their premier example) and thus were historically associated with high inequality. In contrast, the endowments of North America lent themselves to commodities grown on family farms and thus promoted the growth of a large middle class. The ES work suggests a natural instrument for inequality: the exogenous suitability of land for wheat versus sugarcane. This instrument is particularly attractive because it picks out the variation due to structural inequality rather than that due to market inequality.

Although it may appear that the suitability of land for wheat versus sugar is simply proxying for whether the country is in the tropics, Easterly provides evidence that there is considerable variation in this variable in both tropical and non-tropical areas. Furthermore, he finds that the differential explanatory power of this IV in the first stage regression survives intact when tropics is independently controlled for.

We examine the correlation between wealth inequality and its two components (politically unconnected and politically connected wealth inequality) and the IV used in Easterly (2007) - the exogenous suit-

\footnotetext{
${ }^{22} \mathrm{~A}$ higher rank on the Corruption Perceptions Index indicates that a country is perceived as being more corrupt by experts knowledgeable about the country. In the most recent 2012 rankings by Transparency International, Denmark, Finland, and New Zealand shared the $1^{\text {st }}$ spot and were viewed as the least corrupt countries in the world, whereas Afghanistan, North Korea, and Somalia shared the $174^{\text {th }}$ spot and were perceived as most corrupt countries in the world.

${ }^{23}$ Full details are provided in Data Appendix A.4.
} 
ability of land for wheat versus sugar (LWHEATSUGAR). ${ }^{24}$ The value of the IV does not vary for a given country over time, and this relationship therefore can only be examined in models without country-specific fixed effects. We hence examine it in a cross-sectional setup. In order to maximize the size of our sample, we include all countries that have billionaires in any of the four years considered and we average the value of wealth inequality (and its components) across the four years. The results are presented in Table 5.

[Table 5 about here.]

As may be seen from Table 5, politically connected wealth inequality bears a statistically significant relationship with LWHEATSUGAR, whereas wealth inequality and politically unconnected wealth inequality do not. The negative correlation between LWHEATSUGAR and politically connected wealth inequality indicates that countries that have a higher proportion of land exogenously suitable for wheat relative to sugarcane (and which have relatively lower levels of structural inequality) are associated with lower levels of politically connected wealth inequality. Conversely, countries where more land is suitable for growing sugarcane than growing wheat are characterized by a higher level of structural inequality and are also associated with higher levels of politically connected wealth inequality. Overall, the results in Table 5 offer suggestive evidence that politically connected wealth inequality maps onto Easterly's structural inequality, whereas wealth inequality and politically unconnected wealth inequality encompass both market-based and structural inequality and do not bear a statistically significant relationship with the instrument developed in Easterly (2007).

The results in Table 4 and Table 5 also suggest that our two components of wealth inequality are not strongly correlated with each other. A graph showing the patterns of correlation between these two components of wealth inequality for each year individually for those countries that have billionaires is provided in Figure 2. The lack of correlation between the two components of wealth inequality is evident from the figure and confirmed from the correlation coefficients of $-0.2324,-0.1814,0.0098$, and -0.0661 for 1987, 1992, 1996, and 2002, respectively. In addition, the list of countries with the five highest levels of politically unconnected wealth inequality is completely disjoint from the list of countries with the five highest levels of politically connected wealth inequality. ${ }^{25}$ The lack of high correlation between the two variables also permits us to include them simultaneously in the same regression.

[Figure 2 about here.]

\section{Empirical Results}

In Section 5.1, we present the results from our base specification - a fixed effects model with lagged values of the explanatory variables in which billionaire wealth is normalized by GDP, physical capital stock, and

\footnotetext{
${ }^{24}$ The LWHEATSUGAR ratio is defined by Easterly (2007) as LWHEATSUGAR=log [(1+share of arable land suitable for wheat) / (1+share of arable land suitable for sugarcane)]. Easterly uses data from the FAO about the percent of national arable land area suitable for different crops, taking into account such factors as soil, rainfall, temperature, and elevation.

${ }^{25}$ The countries with the highest level of politically unconnected wealth inequality are Hong Kong, Philippines, Singapore, Kuwait, and Switzerland, whereas the countries with the highest level of politically connected wealth inequality are Malaysia, Colombia, Indonesia, Thailand, and Mexico.
} 
population, respectively. In Section 5.2, we examine why our results differ from those obtained by Ravallion (2012) and Forbes (2000). Finally, in Section 5.3 we summarize the results of a number of robustness checks.

\subsection{Base Specification}

In Table 6 we report the estimates of equation (1), with wealth inequality, income inequality, and initial poverty being the key explanatory variables. The data are from countries reporting some incidence of poverty as measured by $\$ 2$ per day. The Hausman test indicates that the fixed effects specification is more appropriate than the random effects specification in each case and in Table 6 we therefore report the fixed effects estimates. ${ }^{26}$ Estimates from the random effects specification yield similar results and they are reported in Table 9 as part of our robustness checks.

In column (1) of Table 6 we present results from the specification in which wealth inequality is defined as billionaire wealth divided by GDP, while estimates in columns (2) and (3) come from specifications where wealth inequality is defined as billionaire wealth divided by the country's physical capital stock and population, respectively.

[Table 6 about here.]

As may be seen from columns (1)-(3), the effect of wealth inequality on growth is negative and significant at the $10 \%$ significance test level when billionaire wealth is divided by GDP, negative and significant at the $1 \%$ significance test level when billionaire wealth is divided by population, and negative with a pvalue of 0.121 when billionaire wealth is divided by physical capital stock. The effect of income inequality on growth is positive but statistically insignificant when billionaire wealth is divided by GDP or population, and it is positive and significant at the $10 \%$ significance test level when billionaire wealth is divided by physical capital stock. The effect of poverty is insignificant in all three specifications. Our base estimates hence suggest that when all three key regressors are included in the equation, wealth inequality is systematically the most significant determinant of economic growth. Income inequality is of relatively marginal significance, while poverty is not statistically significant in any of the runs.

In columns (4)-(6) of Table 6, we report estimates from the specification where politically unconnected and politically connected billionaire wealth inequality are entered as two separate explanatory variables, along with income inequality and poverty. The results indicate that in all three specifications it is politically connected wealth inequality that has a significant negative effect on growth while politically unconnected wealth inequality does not. The estimated effects of both income inequality and poverty are insignificant in all three specifications. These results hence suggest that it is important to distinguish the nature of wealth inequality in drawing inferences about the effect of wealth inequality on growth and they highlight the negative effect of politically connected wealth inequality in comparison to the insignificant impact of politically unconnected wealth inequality. Moreover, they strengthen our earlier finding that income inequality and poverty are not significant determinants of growth.

\footnotetext{
${ }^{26}$ E.g., for column (1), $\chi 2=99.06$, and Probability $>\chi 2=0.0000$.
} 
In terms of the economic significance of the estimated impact of wealth inequality, note that the 0.132 coefficient on wealth inequality in column (1) implies that a one standard deviation (3.72\%) increase in the level of wealth inequality would result in a $0.49 \%$ decrease in real GDP per capita growth. This is similar to the $0.6 \%$ estimate by Perotti (1996) and somewhat smaller than the $0.8 \%$ effect reported by Alesina and Rodrik (1994), with both of these studies using income inequality as a proxy for wealth inequality and examining the relationship in a cross-country cross-sectional framework. Using the estimates in column (4) of Table 6, one can show that a one standard deviation increase in the level of politically connected wealth inequality, holding constant the level of politically unconnected wealth inequality, results in a $0.60 \%$ slowdown in per capita GDP growth. Given that the mean per capita GDP growth over the period 1987-2007 was $1.9 \%$, this slowdown of $0.60 \%$ represents nearly a third of the average growth rate in GDP per capita. The negative effect of politically connected wealth inequality on growth is hence quite sizable.

The estimated effects of the control variables are in line with what has been reported elsewhere in the literature. The effect of initial income is negative and significant at the $1 \%$ test level, thus providing support for the conditional convergence hypothesis that countries relatively close to their steady-state output level will experience a slower rate of growth. The coefficient on the price level of investment is also negative as is common. The coefficient on the variables corresponding to male and female schooling are positive but not significant. These coefficients are similar to those found in other growth models estimated using the same technique (e.g., Caselli et al., 1996).

\subsection{Reconciling our results with those of Ravallion (2012) and Forbes (2000)}

In order to gain an understanding of what causes the difference between our results in Table 6 and those of Ravallion (2012), who reports a positive and significant effect of poverty on growth together with an insignificant effect of income inequality on growth, we next re-estimate our equations without wealth inequality as an explanatory variable. As may be seen in column (1) of Table 7, we find that the effect of poverty on growth is still insignificant. Moreover, it remains insignificant even when we exclude both wealth and income inequality as explanatory variables (column (2) of Table 7). The insignificant effect of poverty also obtains in most random effects and most OLS estimations (not reported here), and in some of these estimations (including column (5) of Table 7) the effect of poverty on growth is actually positive. The difference in our and Ravallion's (2012) findings is striking and we conjecture that it stems from the fact that he uses primarily a cross-sectional OLS approach, while we, like Forbes (2000), use primarily panel data with country fixed effects. $^{27}$

We next examine why our estimates may differ from those of Forbes (2000), who reports a positive and statistically highly significant effect of income inequality on growth. As may be seen from Column (1) of Table 7, when we re-estimate our equations without wealth inequality as an explanatory variable, we find that the effect of income inequality on growth is statistically insignificant. An insignificant effect of income

\footnotetext{
${ }^{27}$ Recall that Ravallion (2012) finds that his estimates continue to be statistically significant in the GMM model. However, his estimated negative effect of poverty on growth becomes insignificant when he switches from an OLS to fixed effects estimation.
} 
inequality on growth is also found when both wealth inequality and poverty are excluded as explanatory variables in column (3) of the table. Hence, the inclusion or exclusion of additional explanatory variables, relative to those used by Forbes (2000), does not affect the significance of the coefficient on income inequality. Coefficients (4) through (6) replicate the results of specifications of columns (1) through (3) but use country random effects instead of country-specific fixed effects.

[Table 7 about here.]

We next check whether the difference between our and Forbes' (2000) results is brought about by the choice of countries. We exclude poverty and re-estimate our equations on the subset of countries used by Forbes (2000). The estimates, reported in Panel A of Table 8 show that our three measures of wealth inequality have a negative effect that is statistically significant at the $1 \%$ test level, while the effect of income inequality is positive but statistically insignificant. The use of Forbes' (2000) sample of countries hence does not materially affect the impact of wealth inequality, but it does not generate the positive effect of income inequality identified by Forbes (2000).

We next explore whether the difference in the time period covered by Forbes (2000) and our study (1965-1995 vs. 1987-2007) could explain the difference in our and Forbes' (2000) estimates. In order to do so, we use the same subset of countries as Forbes (2000) but allow the effects of wealth and income inequality to vary between the 1987-1997 and 1997-2007 periods. The estimated coefficients, reported in Panel B of Table 8 show that the effects of our three measures of wealth inequality are negative in the second period and since the differences in these effects between the second and first period are not statistically significant, they are negative and significant in the entire 1987-2007 period. The estimated effect of income inequality is insignificant in the second period, but the coefficient on income inequality interacted with the dummy variable for the first period (1987-1997) is positive and statistically significant in the specification where wealth inequality is excluded. These results are hence consistent with Forbes' (2000) finding that the effect of income inequality was positive in 1987-1997 (the part of our sample period that overlaps with that of Forbes, 2000) when wealth inequality was not included as a regressor. That pattern is reaffirmed when we look at the estimated coefficients from the full model reported in columns (2)-(4) of Panel B of Table 8. The coefficient on income inequality is generally significant in these specifications in the first (1987-97) period, and it becomes insignificant thereafter.

[Table 8 about here.]

Our estimates in Tables 7 and 8 hence support the conclusion we drew earlier that wealth inequality has a negative effect on economic growth. Moreover, we find that the effect of initial poverty is statistically insignificant irrespective of whether wealth inequality is included or excluded as a regressor as long as the variable is introduced in a panel set-up with country fixed or random effects - a likely reason why our estimated effect of poverty differs from the negative OLS estimate of Ravallion (2012). Finally, we are able to replicate Forbes' (2000) positive effect of income inequality on growth in the early (1987-1997) period 
when wealth inequality is excluded, but we show that the effect becomes less robust when wealth inequality is included. Interestingly, the effect of income inequality becomes insignificant in the post-1997 period, suggesting that wealth rather than income inequality has started to play an increasingly important part. It is worth noting that our results are consistent with those of Deininger and Olinto (2000) who include land inequality (their proxy for wealth inequality) and income inequality in the same specification in a panel setup. They find that the coefficient on land inequality is negative and significant, while the coefficient on income inequality is positive and occasionally significant.

\subsection{Additional Robustness Checks}

In this section we report the results of additional robustness checks and show that the results for the base specification presented in Section 5.1 hold up. In order to conserve space, in Table 9 we report results from the robustness checks without including coefficients on the other control variables. Full results are available from the authors upon request.

(a) RC1: Robustness to Forbes magazine's choice of countries for the billionaires in the data set: As described in Data Appendix A.1, in a total of 30 (less than 2\%) of the 1,652 entries we assign a person a different country than what was assigned to him by Forbes magazine. We examine the robustness of our results to Forbes magazine's assignment of country and find that the results remain essentially unchanged.

(b) RC2: Use of alternative econometric approaches:

(i) Use of a random effects instead of a fixed effects specification: Our use of the country fixed effects model is justified by the results of the Hausman test. In all cases, the Hausman test rejects the null hypothesis of no correlation between the unobserved country-specific random effects and the explanatory variables, implying that random effects estimates are biased and inconsistent. However, we have also estimated the random effects specification as Griliches and Hausman (1986) stress that observing similar estimates across alternative panel data estimation techniques signals the absence of serious errors-in-variables problems. Using the random effects specification, we find the wealth inequality has a negative and generally statistically significant effect on growth at the $10 \%$ level in the first specification, $13 \%$ level in the second, and $1 \%$ level in the third specification. Similarly, politically connected wealth inequality has a coefficient that is negative and statistically significant at the $1 \%$ level (in 2 of the 3 specifications) and at the $5 \%$ level (in the remaining specification). Politically unconnected wealth inequality continues to be statistically insignificant all throughout.

(ii) Using instrumental variables: Finding valid IVs in a non-experimental setting is obviously difficult. We have, in the end, found two IVs that satisfy the formal test criteria. They yield similar results as the other methods we use, but have conceptual weaknesses. The first IV strategy relies on decomposing billionaire wealth normalized by GDP into the product of average billionaire wealth divided by per capita income and the number of billionaires divided by population. It is motivated by the 
fact that the average billionaire wealth in any given country is strongly correlated with the contemporaneous average billionaire wealth in the region to which a country belongs. Beyond its association with average billionaire wealth of a country, one may argue that the average billionaire wealth in other countries in the same region does not affect a country's economic growth. On this basis one can use average regional billionaire wealth, excluding the own country, as an instrument for own-country billionaire wealth.

The other IV that we have used is the exchange rate. This choice may be motivated by the fact that Forbes magazine only includes people on the list if their wealth is in excess of $\$ 1$ billion when expressed in USD. One can therefore use the exchange rate as an IV under the assumption that it affects measured wealth inequality but does not affect growth through other means. We obtain estimates that are very similar to what we found using regional average billionaire wealth. The results using either IV approach are available from the authors on request.

(c) RC3: Robustness to inclusion of additional explanatory variables:

(i) Adding a measure of institutional quality: The inclusion of country fixed effects deals with the problem of omitted variable bias in that all country-specific factors that are invariant over time (e.g. a country's legal origin) are controlled for by the country fixed effect. However, the fixed effects specification does not deal with country-specific factors that may vary over time. Given the importance that the literature assigns to institutional quality (e.g., Rodrik, Subramanian, and Trebbi, 2004), we examine the robustness of our results to the inclusion of a measure of institutional quality. We employ the very widely used Economic Freedom Index constructed by the Fraser Institute and we find that controlling for this aggregate measure of institutional quality does not alter any of the findings of our paper.

(ii) Controlling for the exchange rate: The Forbes' billionaire list converts wealth in local currency into U.S. dollars using the current exchange rates. Fluctuations in the exchange rates thereby induce a variation in the measure of wealth inequality even when the true underlying level of wealth inequality in the country is unchanged. We examine the robustness of our results to inclusion of the exchange rate as a control. We also re-estimate the regression only on those observations for which the variation in the exchange rate from one period to the next is within $5 \%$ to $95 \%$ of the distribution of change in exchange rates. In both cases, we find that our basic results continue to hold and are robust to the inclusion of the exchange rate control.

(d) RC4: Using $\$ 1.25$ per day per person as the poverty line: Thus far we have used a headcount measure of poverty based on the fraction of individuals consuming less than $\$ 2$ per person per day, as used by Ravallion (2012). In addition, like him, we also consider for robustness a lower consumption threshold of $\$ 1.25$ per day per person which is the expected value of the poverty line in the poorest countries. The results obtained with such a threshold are very similar to those obtained previously.

[Table 9 about here.] 


\section{Concluding Remarks}

A central question in the social sciences is whether inequality in control over a society's resources facilitates or hinders economic growth. The issue has been intensively studied but is far from settled, in part because theoretical arguments have been largely based on the distribution of wealth, while empirical studies have been forced to use the distribution of income as a proxy. We bridge this gap by deriving the first global measure of wealth inequality, focusing on the concentration of wealth at the very top of the pyramid, and estimating the effect of this wealth inequality on economic growth. In addition, motivated by Ravallion's (2012) recent finding that poverty rather than income inequality determines economic growth, we provide the first direct comparison of the effects of wealth inequality, income inequality, and poverty on growth. Finally, we generate measures of politically connected and politically unconnected wealth inequality and estimate their respective effects on growth.

Our first key finding is that wealth inequality tends to have a negative effect on economic growth, income inequality has no or at most a weak positive effect on growth, and the effect of poverty on growth is insignificant. The reason why the positive growth effect of income inequality found in a leading earlier study (Forbes, 2000) is less statistically significant in our data appears to be brought about by the exclusion of wealth inequality in Forbes' (2000) specification and by weakening of the previously positive growth effect of income inequality from the mid-to-late 1990s on. As to the fact that we find an insignificant effect of poverty on economic growth, we conclude that it stems from the fact that Ravallion (2012) uses primarily a cross-sectional OLS approach, while we, like Forbes (2000), use primarily panel data with fixed effects.

Our second key finding is that when we enter politically connected and unconnected wealth as two separate explanatory variables into our regressions, it is politically connected wealth inequality that has a significant negative effect on growth, while the effects of politically unconnected wealth inequality, income inequality, and poverty are all insignificant.

Our finding that it is politically connected rather than politically unconnected wealth that dampens growth may be illustrated by two country-specific examples. The first example is Mexico's telecom industry where the world's wealthiest individual, Carlos Slim Helu, built his fortune. Comparing prices of residential and business telecommunications in all OECD countries, OECD's (1999) report concluded that "in both cases Mexico's prices are well above the OECD average." OECD (1999) also found that the cost of the basket of telecommunications services used by consumers in Mexico, measured in US dollars using Purchasing Power Parity indices, is about three times that of the OECD. Moreover, Mexican investment in information and communications technologies, a field that is dominated by Carlos Slim Helu's Telmex, was at 3.1 percent of GDP, lagging developed countries such as Japan at 7.4 percent, the United States at 8.8 percent, and even regional peers with healthier competition in telecom such as Chile at 6.7 percent and Brazil at 6.9 percent (Foreign Policy, October 11, 2007). Finally, the high price of telecommunication services coupled with the low levels of investment have resulted in by far the lowest penetration rate of telephones among 
OECD countries. ${ }^{28}$ This is in spite of the fact that Telmex was given the right to charge high access rates to competitors because it was to use the extra income to get more phones to more people (OECD, 1999).

Indonesia's tobacco industry provides another telling example of the effects of political connectedness. ${ }^{29}$ The influence of the tobacco industry on government policy is enormous and Indonesia is the only country in Asia to have not signed the WHO Framework Convention on Tobacco Control (WHO FCTC), a treaty that as of September 2013 had been signed by 177 parties, including Iran, North Korea, Syria, and Sudan. The FCTC addresses a number of issues, such as promoting taxation as a way to reduce cigarette consumption, imposing restrictions on smoking in public places, enacting comprehensive bans on tobacco advertising, promotion and sponsorship within five years of ratification, putting larger health warnings on cigarette packs, and intensifying the fight against tobacco smuggling (The Jakarta Post, 2008). Indonesia has not signed the convention in spite of the fact that it is a country in which Muslims constitute approximately 86 percent of the population and "smoking is either completely prohibited in Islam or abhorrent to such a degree as to be prohibited." (WHO Regional Office for the Eastern Mediterranean). The effect of the tobacco industry on the Indonesian economy is also evident from the fact that Indonesia's average tobacco tax of 37 per cent is the lowest in Southeast Asia and well below the global average of 70 per cent of the sales price (South China Morning Post, 2008).

These and other examples, together with our econometric results, suggest that the policy debate about sources of economic growth ought to focus on the distribution of wealth rather than on the distribution of income. Moreover, particular attention ought to be paid to politically connected concentration of wealth as a possible cause of slower economic growth. Further research in this area is obviously needed, especially with respect to the effects of wealth inequality at different parts of the wealth distribution, the possibly declining effect of unequal distribution of income on growth, and the role of poverty.

\footnotetext{
${ }^{28} \mathrm{As}$ OECD (1999) reported, at the start of 1998 Mexico had less than 10 telephones per 100 inhabitants, while Poland, the next worst performer among OECD countries, had 20. Moreover, no new access lines were added in Mexico in 1996 and 1997.

${ }^{29}$ Two of the three richest billionaire entities in Indonesia as of 2012, R. Budi \& Michael Hartono and Susilo Wonowidjojo, owe their fortunes to tobacco-related industries (Forbes, 2012).
} 


\section{References}

[1] Aghion, Philippe, Eve Caroli, and Cecilia García-Peñalosa, "Inequality and Economic Growth: The Perspective of the New Growth Theories," Journal of Economic Literature 37:4 (1999), 1615-1660.

[2] Alesina, Alberto and Dani Rodrik, "Distributive Politics and Economic Growth," Quarterly Journal of Economics 109:2 (1994), 465-490.

[3] Attanasio, Orazio and Chiara Binelli, "Inequality, Growth and Redistributive Policies", in Conference on Poverty, Inequalities and Growth: What's at stake for development aid?, Afd/EUDN, Paris, (2003).

[4] Bakija, Jon, Adam Cole and Bradley Heim, "Jobs and Income Growth of Top Earners and the Causes of Changing Income Inequality: Evidence from U.S. Tax Return Data”, Working Paper, (2012).

[5] Barro, Robert J., “Inequality, growth, and investment,” NBER Working Paper No. 7038, (1999).

[6] _ _Inequality and Growth in a Panel of Countries," Journal of Economic Growth 5:1 (2000), 5-32.

[7] Barro, Robert J. and Jong-Wha Lee, "International Data on Educational Attainment: Updates and Implications," Oxford Economic Papers 53:3 (2001), 541-563.

[8] Bénabou, Roland, "Inequality and Growth," NBER Chapters, in NBER Macroeconomics Annual 11 (1996), 11-92, (Cambridge: National Bureau of Economic Research, Inc.)

[9] Bertrand, Marianne, Esther Duflo, and Sendhil Mullainathan, "How Much Should We Trust Differences-in-Differences Estimates?" Quarterly Journal of Economics 119:1 (2004), 249-275.

[10] Bourguignon, François, "Pareto-Superiority of Unegalitarian Equilibria in Stiglitz' Model of Wealth Distribution with Convex Savings Function,” Econometrica 49:6 (1981), 1469-1475.

[11] Brandolini, Andrea and Timothy Smeeding, "Income Inequality in Richer and OECD Countries (pp. 71-100)," in W. Salverda, B. Nolan, and T. M. Smeeding (Ed.), Oxford Handbook of Economic Inequality, (Oxford, Oxford University Press, 2009).

[12] Caselli, Francesco, Gerardo Esquivel, and Fernando Lefort, "Reopening the Convergence Debate: A New Look at Cross-Country Growth Empirics," Journal of Economic Growth 1:3 (1996), 363-389.

[13] Davies, James B., Susanna Sandström, Anthony Shorrocks, and Edward N. Wolff, "The World Distribution of Household Wealth," World Institute for Development Economic Research (UNU-WIDER) Working Paper no. DP2008/03, (2008).

[14] Deininger, Klaus W. and Pedro Olinto, “Asset distribution, inequality, and growth”, World Bank Policy Research Working Paper Series, No. 2375, (2000).

[15] Deininger, Klaus W. and Lyn Squire, "New Ways of Looking at Old Issues: Inequality and Growth," Journal of Development Economics 57:2, (1998), 259-287. 
[16] De La Croix, David, and Matthias Doepke, "Inequality and growth: Why differential fertility matters," American Economic Review 93:4 (2003), 1091-1113.

[17] Diallo Ibrahima Amadou, "STOCKCAPIT: Stata module to calculate physical capital stock by the perpetual-inventory method," Statistical Software Components S457270, Boston College Department of Economics, revised 17 Jun 2011.

[18] Easterly, William, "Inequality does cause underdevelopment: Insights from a new instrument," Journal of Development Economics 84:2 (2007), 755-776.

[19] Ehrhart, Christophe, "The effects of inequality on growth: a survey of the theoretical and empirical literature," ECINEQ Working Paper No. 2009-107, (2009).

[20] Engerman, Stanley L. and Kenneth L. Sokoloff, "Factor Endowments, Institutions, and Differential Paths of Growth Among New World Economies: A View from Economic Historians of the United States (pp. 260-304)," in Stephen Haber (Ed.), How Latin America Fell Behind, (Stanford: Stanford University Press, 1997).

[21] Fields, Gary S., Distribution and development: A new look at the developing world, (Russell Sage Foundation, New York: The MIT Press, 2001).

[22] Fisman, Raymond, "Estimating the Value of Political Connections," American Economic Review, 91:4 (2001), 1095-1102.

[23] Forbes, Kristin J "A Reassessment of the Relationship between Inequality and Growth," American Economic Review 90:4 (2000), 869-887.

[24] Forbes Magazine, List of Billionaires, 1987, 1992, 1996, 1997, and 2002 issues.

[25] Galbraith, James, "Inequality, unemployment and growth: New measures for old controversies," Journal of Economic Inequality 7:2 (2009), 189-206.

[26] Galor, Oded, and Joseph Zeira, “Income Distribution and Macroeconomics," Review of Economic Studies 60:1 (1993), 35-52.

[27] Galor, Oded, "Inequality and Economic Development: The Modern Perspective" (Edward Elgar Publishing Ltd., Northampton, MA, 2009).

[28] Griliches, Z., and J.A. Hausman, "Errors in variables in panel data," Journal of Econometrics 31:1 (1986), 93-118.

[29] Gupta, Dipak, “The Economics of Political Violence” (Praeger, New York, 1990).

[30] Gwartney, James, Joshua Hall, and Robert Lawson, “2011 Economic Freedom Dataset,” published in Economic Freedom of the World: 2010 Annual Report, Economic Freedom Network (2011), Data retrieved from http://www.freetheworld.com/2011/2011/Dataset.xls. 
[31] Heston, Alan, Robert Summers, and Bettina Aten, "Penn World Table Version 6.2," Center for International Comparisons of Production, Income and Prices at the University of Pennsylvania, (Sep. 2006).

[32] International Country Risk Guide, http://www.icrg.net, (2005).

[33] Kaldor, Nicholas, "Alternative theories of distribution," Review of Economic Studies 23:2 (1956), $83-100$.

[34] — “Capital accumulation and economic growth (pp. 177-202)," in F.A. Lutz and D.C. Hague (Eds.), The Theory of Capital, (St. Martin's Press, New York, 1961).

[35] Kuznets, Simon, "Economic Growth and Income Inequality," American Economic Review, 45:1 (1955), $1-28$.

[36] Levine, Ross, and David Renelt, "A Sensitivity Analysis of Cross-Country Growth Regressions," American Economic Review 82:4 (1992), 942-963.

[37] Meltzer, Allen, and Scott Richard, "A rational theory of the size of government," Journal of Political Economy, 89:5 (1981), 914-927.

[38] Mobarak, Ahmed Mushfiq and Denni Purbasari, "Political Trade Protection in Developing Countries: Firm Level Evidence from Indonesia,” Working Paper, (2005). SSRN: http://ssrn.com/abstract=770949.

[39] Morck, Randall, David Stangeland, and Bernard Yeung, "Inherited Wealth, Corporate Control, and Economic Growth: The Canadian Disease (pp. 319-369)," in Randall Morck (Ed.), Concentrated Corporate Ownership, (Chicago: University of Chicago Press, 2000).

[40] Morck, Randall, Daniel Wolfenzon, and Bernard Yeung, "Corporate Governance, Economic Entrenchment, and Growth," Journal of Economic Literature 43:3 (2005), 655-720.

[41] Nehru, Vikram, and Ashok Dhareshwar, "A New Database on Physical Capital Stock: Sources, Methodology and Results," Revista de Analisis Economica 8:1 (1993), 37-59.

[42] Nickell, S. "Biases in dynamic models with fixed effects," Econometrica 49:6 (1981), 1417-1426.

[43] Organisation for Economic Cooperation and Development (OECD), "Regulatory reform in Mexico," (1999).

[44] Perotti Roberto, "Growth, Income Distribution and Democracy: What the Data Say," Journal of Economic Growth 1:2 (1996), 149-187.

[45] Persson, Torsten and Tabellini, Guido, "Is Inequality Harmful for Growth?" American Economic Review $84: 3$ (1994), 600-621.

[46] Piketty, Thomas and Emmanuel Saez, "Income Inequality in the United States, 1913-1998”, Quarterly Journal of Economics, 118:1 (2003), 1-39. 
[47] Ravallion, Martin, “Why Don’t We See Poverty Convergence?” American Economic Review 102:1 (2012), 504-523.

[48] Rodrik, Dani, Arvind Subramanian, and Francesco Trebbi, "Institutions Rule: The Primacy of Institutions Over Geography and Integration in Economic Development," Journal of Economic Growth 9:2 (2004), 131-165.

[49] Schaffer, M.E., "xtivreg2: Stata module to perform extended IV/2SLS, GMM and AC/HAC, LIML and k-class regression for panel data models," (2010), http://ideas.repec.org/c/boc/bocode/s456501.html

[50] Smeeding, Timothy M., "Public Policy, Economic Inequality, and Poverty: The United States in Comparative Perspective," Social Science Quarterly 86:S1 (2005), 955-983.

[51] Sokoloff, Kenneth L. and Stanley L. Engerman, "Institutions, Factor Endowments, and Paths of Development in the New World," Journal of Economic Perspectives 14:3 (2000), 217-232.

[52] South China Morning Post, "Where there’s smoke," (25 September, 2008).

[53] Stiglitz, Joseph E., “The Price of Inequality,” (W. W. Norton \& Company, New York, 2012).

[54] Stock, James H., and Mark W. Watson, "Introduction to Econometrics (2nd Edition)," (Addison Wesley, Boston, MA, 2002).

[55] The Economist, "For richer, for poorer", (2012).

[56] Voitchovsky, Sarah, "Does the Profile of Income Inequality Matter for Economic Growth?: Distinguishing between the Effects of Inequality in Different Parts of the Income Distribution.” Journal of Economic Growth 10:3 (2005), 273-296.

[57] Wijaya, Astrid, "Government powerless against tobacco giants," The Jakarta Post, Jakarta, (November $132008)$.

[58] Winter, Brian, "How Slim Got Huge," Foreign Policy, (October 11, 2007).

[59] Wolff, Edward N. "International Perspectives on Household Wealth," (Elgar Publishing Ltd., Northampton, MA, 2006).

[60] World Bank, Development Research Group, PovcalNet: the on-line tool for poverty measurement (Washington DC: World Bank, 2013). Available: http://iresearch.worldbank.org/PovcalNet/index.htm?0

[61] World Institute for Development Economics Research, World Income Inequality Database, (Helsinki: WIDER, 2004). Available: http://www.wider.unu.edu/research/Database/en_GB/wiid/ 


\section{A Data Appendix}

\section{A.1 Construction of billionaire lists}

Forbes Magazine published a list of the four hundred richest individuals in the United States, the so-called Forbes Four Hundred for the first time in 1982. It was then followed by the publication of a list of individuals and families from all countries from around the world having more than $\$ 1$ billion in wealth (in nominal terms) in 1987. Since then, these lists have been published annually. For all countries of the world but the United States, we exclusively rely on the wealth data provided in the billionaire lists. In the case of the United States only, where additional information is available from the Forbes Four Hundred, we also use the information contained therein and aggregate the wealth of family members whose individual amounts of wealth are below a billion dollars but cumulatively sum up to more than a billion dollars. We add them to the list of billionaires to get an augmented list. This step is necessary in order to make the numbers comparable for the United States over all four years of the sample. All of our results are robust to the exclusion of United States from the sample.

In the vast majority of the cases, the locus of business activities for a billionaire is the same as the person's country of origin and/ or his country of birth. However, they do not match up in all cases. When that happens, we depart from Forbes magazine's chosen categorization of country and instead assign him to the country where he presently resides and maintains his business activities. For example, in the case of Stelios Haji-Ionnanou of EasyAir whose business activities are currently based in the U.K. where he spends a considerable fraction of his time, we classify him as British. However considering his Greek origin, Forbes classifies him as Greek. Likewise in the case of Lakshmi Mittal of ArcelorMittal who Forbes classifies as Indian considering that he is of Indian origin, we choose to classify him as British since he moved out of India in the late 1970s and has been settled in London, U.K. since 1995. However such circumstances arise in only 30 of the 1,652 entries on our list, or less than $2 \%$ of the total number of entries. These 30 billionaires who we categorize against a particular country different from Forbes' initial classification account for less than $2 \%$ of the total billionaire wealth and the results we obtain for wealth inequality are robust to whether we go with our choice of a country or with Forbes' magazine original assignment of country.

Finally, Forbes magazine changed its editorial policy for four years, between 1997 and 2000. In these years, they included only those billionaires who were either self-made (e.g. Warren Buffett) or those who inherited their wealth and were actively managing it themselves (e.g. Carlos Slim Helu of Mexico). This leads to the exclusion of billionaires from around the world who simply inherited their wealth and were no longer actively involved themselves in growing their businesses, such as the duPonts and Rockefellers in the U.S., the Quandt family of Germany (the largest share holder of BMW), and Liliane Bettencourt of France (the largest share holder of L'Oreal) to provide a few examples. ${ }^{30}$ Thus while the three other years of the

\footnotetext{
${ }^{30}$ This is how Forbes described its change in editorial policy in 1997: "Ten years ago Forbes started counting billionaires outside the U.S. We found 96. Last year, 298-plus 149 American billionaires. With stock markets around the world up an average $23 \%$ in the last year, the billionaire population, like the deer population, is sure to have increased. Bowing to economic reality, we have revised our selection process this year. A billion bucks no longer gets you in. You've got to have made it yourself, or you've got to be actively managing it. This eliminates a fair number of jet-setters and Palm Beach residents. We have culled the roster of billionaires down to
} 
panel - 1987, 1992, and 2002 included all categories of billionaires, including those who simply inherited their wealth and were not actively managing it themselves such as those mentioned above, the 1997 list, generally failed to include them by design making it challenging to have the lists comparable across the four years. Given this limitation of the 1997 list, we use the 1996 list instead, assuming that had Forbes chosen to include all billionaires in their 1997 listing, then the measures of wealth inequality and political connections we would have arrived at for 1997 are similar to what we arrive at by looking at the 1996 list. That said, the correlation coefficient between wealth inequality, constructed from the 1996 and 1997 lists is 0.9456 ( $\mathrm{p}$-value $=0.0000$ ) and that between politically connected wealth inequality for the two years is 0.9600 ( $p$-value $=0.0000$ ). The regression results obtained by using the 1997 list instead of the 1996 list are similar to those reported in the paper and are available on request.

\section{A.2 Countries that appear on the Forbes' billionaire list at least once in the four years - 1987, 1992, 1996, and 2002 and level of wealth inequality in those countries}

[Table A.1 about here.]

\section{A.3 Classifying billionaires as politically connected or not}

The following are three examples of brief news reports that resulted in classification of billionaires as "politically connected."

1. The first example is of an Indonesian magnate, Prajogo Pangestu.

In any case, there's no denying that Indonesian government agencies have helped Mr. Prajogo make the leap from a successful timber merchant to a major corporate force. His Barito Group of companies, for example, is the state banking system's largest borrower, with loans of more than $\$ 1$ billion outstanding, and benefits from an unusually attractive 1992 debt rescheduling [Emphasis added] that stretched repayment periods on about $\$ 460$ million in timber industry borrowings into the next century. Mr. Prajogo, Mr. Bambang and their partners also stand to gain from a change of government policy last year that allowed them to proceed with their postponed \$1.6 billion PT Chandra Asri petrochemical project, the products of which will be protected by steep new tariffs [Emphasis added] on imports. (The Wall Street Journal Asia, 1993)

2. We next provide Forbes magazine's description of the Birla family, India's only billionaire entry until 1996:

The nationalists who later became free India's power elite rewarded the Birla family with lucrative contracts. After independence, the Birlas continued their lavish contributions to the 
ruling Congress Party. So accomplished are they in manipulating the bureaucracy, and so vast their network of intelligence, that they frequently obtain preemptive licenses, enabling them to lock up exclusive rights for businesses as yet unborn [Emphasis added] (Forbes, 1987).

3. Lastly, the following description pertains to Russian billionaire, Mikhail Fridman who shows up on the Forbes' list in 2002:

Mikhail Fridman founded OAO Alfa Bank in 1991 and soon after recruited Pyotr Aven, former minister of foreign economic relations, to raise Alfa's political profile. The partners were among a handful of businessmen who helped to finance Boris Yeltsin's re-election campaign in 1996. The Kremlin rewarded these men by selling them state-owned oil and metals companies at bargainbasement prices [Emphasis added] (The Wall Street Journal, 2001).

\section{A.4 Ranking of countries with the highest and lowest levels of politically con- nected billionaire wealth on Transparency International's Corruption Per- ceptions Index for 1995 and 2012}

The following table offers the rank on Transparency International's Corruption Perceptions Index (CPI) for the six countries with the lowest average level of politically connected wealth inequality which show up in each of the four years of our sample and the five countries with the highest average level of politically connected wealth inequality. Transparency International (TI) was formed in May 1993 but the first CPI was not published until 1995. We report the rank of each country on the CPI for 2012, the last year for which the index is available and 1995. A country that has an higher absolute rank on the index is perceived as more corrupt than a country with a lower absolute rank on the index. For example, Indonesia ranked at 118 in 2012 is perceived as more corrupt than Hong Kong which is ranked at 14 on the index.

[Table A.2 about here.] 
Table 1: Summary statistics for Forbes' billionaire data

\begin{tabular}{|c|c|c|c|c|}
\hline & 1987 & 1992 & 1996 & 2002 \\
\hline No. of countries with billionaires & 23 & 31 & 37 & 41 \\
\hline Total billionaire wealth (billions $\$$ ) & $\$ 353$ & $\$ 612$ & $\$ 1,152$ & $\$ 1,649$ \\
\hline Billionaire wealth, normalized by GDP & $3.5 \%$ & $3.5 \%$ & $7.6 \%$ & $5.4 \%$ \\
\hline $\begin{array}{l}\text { Billionaire wealth, normalized by physical } \\
\text { capital stock }\end{array}$ & $0.69 \%$ & $0.90 \%$ & $1.7 \%$ & $1.2 \%$ \\
\hline $\begin{array}{l}\text { Billionaire wealth, normalized by } \\
\text { population (in } \$ \text { ) }\end{array}$ & $\$ 350$ & $\$ 474$ & $\$ 1,069$ & $\$ 1,020$ \\
\hline $\begin{array}{l}\text { Politically unconnected billionaire wealth } \\
\text { (billions \$) }\end{array}$ & $\$ 307$ & $\$ 544$ & $\$ 1,028$ & $\$ 1,581$ \\
\hline $\begin{array}{l}\text { Politically unconnected billionaire wealth, } \\
\text { normalized by GDP }\end{array}$ & $2.7 \%$ & $2.5 \%$ & $6.2 \%$ & $4.9 \%$ \\
\hline $\begin{array}{l}\text { Politically unconnected billionaire wealth, } \\
\text { normalized by physical capital stock }\end{array}$ & $0.56 \%$ & $0.90 \%$ & $1.5 \%$ & $1.1 \%$ \\
\hline $\begin{array}{l}\text { Politically unconnected billionaire wealth, } \\
\text { normalized by population (in } \$ \text { ) }\end{array}$ & $\$ 323$ & $\$ 431$ & $\$ 994$ & $\$ 982$ \\
\hline $\begin{array}{l}\text { Politically connected billionaire wealth } \\
\text { (billions } \$ \text { ) }\end{array}$ & $\$ 46$ & $\$ 68$ & $\$ 124$ & $\$ 69$ \\
\hline $\begin{array}{l}\text { Politically connected billionaire wealth, } \\
\text { normalized by GDP }\end{array}$ & $0.86 \%$ & $0.95 \%$ & $1.36 \%$ & $0.52 \%$ \\
\hline $\begin{array}{l}\text { Politically connected billionaire wealth, } \\
\text { normalized by physical capital stock }\end{array}$ & $0.13 \%$ & $0.19 \%$ & $0.27 \%$ & $0.082 \%$ \\
\hline $\begin{array}{l}\text { Politically connected billionaire wealth, } \\
\text { normalized by population (in } \$ \text { ) }\end{array}$ & $\$ 29$ & $\$ 43$ & $\$ 75$ & $\$ 34$ \\
\hline
\end{tabular}

The summary statistics are calculated only for the countries with billionaires when they have data on all the covariates. In the process, we lose between 1 to 4 countries given the lack of data on control variables depending on the year.

The billionaire list for 1996 is used instead of the billionaire list for 1997. Reasons for using the 1996 list instead of the 1997 list are mentioned in the text and details are provided in the Data Appendix A.1. 
Table 2: Descriptive Statistics for dependent variable and all control variables

Panel A: Summary Statistics

\begin{tabular}{|c|c|c|c|c|c|c|c|}
\hline & Definition & Source & Period/ Year & Mean & $\begin{array}{l}\text { Std. } \\
\text { Dev. }\end{array}$ & Minimum & Maximum \\
\hline \multirow{4}{*}{ Growth Rate } & \multirow{4}{*}{$\begin{array}{l}\text { Growth in real GDP per } \\
\text { capita }\end{array}$} & IMF World & $1988-1992$ & $1.6 \%$ & $3.9 \%$ & $-7.4 \%$ & $9.2 \%$ \\
\hline & & Economic & $1993-1997$ & $1.7 \%$ & $3.8 \%$ & $-11.4 \%$ & $10.3 \%$ \\
\hline & & Outlook & $1998-2002$ & $1.2 \%$ & $2.2 \%$ & $-3.4 \%$ & $7.4 \%$ \\
\hline & & Database & $2003-2007$ & $3.8 \%$ & $1.7 \%$ & $0.5 \%$ & $10.4 \%$ \\
\hline \multirow{4}{*}{ Income } & \multirow{4}{*}{$\begin{array}{l}\text { Ln of Real GDP per } \\
\text { capita in } 2000 \text { constant } \\
\text { Prices (In International } \\
\text { dollar per person) }\end{array}$} & \multirow{4}{*}{$\begin{array}{l}\text { Penn } \\
\text { World } \\
\text { Tables v6.2 }\end{array}$} & 1987 & 8.09 & 0.71 & 6.58 & 9.23 \\
\hline & & & 1992 & 7.98 & 0.81 & 6.60 & 9.19 \\
\hline & & & 1997 & 8.14 & 0.79 & 6.67 & 9.31 \\
\hline & & & 2002 & 8.24 & 0.76 & 6.79 & 9.44 \\
\hline \multirow{4}{*}{$\begin{array}{l}\text { Female } \\
\text { Schooling }\end{array}$} & \multirow{4}{*}{$\begin{array}{l}\text { Average years of } \\
\text { secondary schooling in } \\
\text { the female population } \\
\text { aged } 25 \text { and above }\end{array}$} & \multirow{4}{*}{$\begin{array}{l}\text { Barro \& } \\
\text { Lee }(2001)\end{array}$} & 1985 & 0.67 & 0.45 & 0.05 & 1.60 \\
\hline & & & 1990 & 0.82 & 0.61 & 0.05 & 2.20 \\
\hline & & & 1995 & 1.00 & 0.68 & 0.06 & 2.49 \\
\hline & & & 2000 & 1.13 & 0.67 & 0.08 & 2.61 \\
\hline \multirow{4}{*}{$\begin{array}{l}\text { Male } \\
\text { Schooling }\end{array}$} & \multirow{4}{*}{$\begin{array}{l}\text { Average years of } \\
\text { secondary schooling in } \\
\text { the male population } \\
\text { aged } 25 \text { and above }\end{array}$} & \multirow{4}{*}{$\begin{array}{l}\text { Barro \& } \\
\text { Lee }(2001)\end{array}$} & 1985 & 1.05 & 0.47 & 0.30 & 1.96 \\
\hline & & & 1990 & 1.16 & 0.61 & 0.13 & 2.37 \\
\hline & & & 1995 & 1.27 & 0.70 & 0.17 & 3.12 \\
\hline & & & 2000 & 1.38 & 0.69 & 0.16 & 3.10 \\
\hline \multirow{4}{*}{ PPPI } & \multirow{5}{*}{$\begin{array}{l}\text { Price level of } \\
\text { investment, measured } \\
\text { as the PPP of } \\
\text { investment/ exchange } \\
\text { rate relative to the USA }\end{array}$} & \multirow{4}{*}{$\begin{array}{l}\text { Penn } \\
\text { World } \\
\text { Tables v6.2 }\end{array}$} & 1987 & 69.8 & 62.9 & 24.9 & 367.6 \\
\hline & & & 1992 & 74.6 & 46.5 & 31.7 & 325.0 \\
\hline & & & 1997 & 68.7 & 21.8 & 22.4 & 111.4 \\
\hline & & & 2002 & 62.1 & 25.8 & 27.0 & 138.6 \\
\hline \multirow{4}{*}{$\begin{array}{l}\text { Wealth } \\
\text { Inequality }\end{array}$} & & Forbes' & 1987 & $0.2 \%$ & $0.6 \%$ & $0.0 \%$ & $2.3 \%$ \\
\hline & \multirow{3}{*}{$\begin{array}{l}\text { Billionaire wealth, } \\
\text { divided by GDP }\end{array}$} & listings \& & 1992 & $0.7 \%$ & $1.5 \%$ & $0.0 \%$ & $7.2 \%$ \\
\hline & & own & 1996 & $2.6 \%$ & $6.2 \%$ & $0.0 \%$ & $28.2 \%$ \\
\hline & & estimates & 2002 & $1.2 \%$ & $2.6 \%$ & $0.0 \%$ & $10.1 \%$ \\
\hline \multirow{4}{*}{$\begin{array}{l}\text { Politically } \\
\text { Unconnected } \\
\text { Wealth } \\
\text { Inequality }\end{array}$} & \multirow{4}{*}{$\begin{array}{l}\text { Politically unconnected } \\
\text { billionaire wealth, } \\
\text { divided by GDP }\end{array}$} & Forbes' & 1987 & $0.0 \%$ & $0.2 \%$ & $0.0 \%$ & $1.1 \%$ \\
\hline & & listings \& & 1992 & $0.3 \%$ & $0.9 \%$ & $0.0 \%$ & $4.7 \%$ \\
\hline & & own & 1996 & $1.8 \%$ & $4.3 \%$ & $0.0 \%$ & $25.6 \%$ \\
\hline & & estimates & 2002 & $0.9 \%$ & $2.0 \%$ & $0.0 \%$ & $10.1 \%$ \\
\hline \multirow{4}{*}{$\begin{array}{l}\text { Politically } \\
\text { Connected } \\
\text { Wealth } \\
\text { Inequality }\end{array}$} & \multirow{4}{*}{$\begin{array}{l}\text { Politically connected } \\
\text { billionaire wealth, } \\
\text { divided by GDP }\end{array}$} & \multirow{4}{*}{$\begin{array}{l}\text { Forbes' } \\
\text { listings \& } \\
\text { own } \\
\text { estimates }\end{array}$} & 1987 & $0.2 \%$ & $0.5 \%$ & $0.0 \%$ & $2.3 \%$ \\
\hline & & & 1992 & $0.4 \%$ & $1.0 \%$ & $0.0 \%$ & $4.3 \%$ \\
\hline & & & 1996 & $0.9 \%$ & $3.0 \%$ & $0.0 \%$ & $18.5 \%$ \\
\hline & & & 2002 & $0.3 \%$ & $1.3 \%$ & $0.0 \%$ & $8.0 \%$ \\
\hline \multirow{5}{*}{$\begin{array}{l}\text { Income } \\
\text { Inequality }\end{array}$} & \multirow{5}{*}{$\begin{array}{l}\text { Gini coefficient of any } \\
\text { quality level and with } \\
\text { either person or } \\
\text { household as the unit of } \\
\text { analysis }\end{array}$} & UNU- & 1987 & 45.5 & 10.4 & 22.7 & 62.0 \\
\hline & & WIDER & 1992 & 48.7 & 9.3 & 29.4 & 69.5 \\
\hline & & World & 1997 & 50.9 & 8.2 & 29.5 & 71.0 \\
\hline & & Income & 2002 & 50.6 & 8.0 & 26.7 & 66.6 \\
\hline & & $\begin{array}{l}\text { Inequality } \\
\text { Database }\end{array}$ & & & & & \\
\hline \multirow{5}{*}{$\begin{array}{l}\text { Headcount } \\
\text { Poverty }\end{array}$} & Percentage of the & & & & & & \\
\hline & population in & $\begin{array}{l}\text { World } \\
\text { Bank }\end{array}$ & 1987 & 47.0 & 31.9 & 0.1 & 96.5 \\
\hline & households with & PovcalNet & 1992 & 48.5 & 31.8 & 0.2 & 95.2 \\
\hline & consumption per capita & tool & 1997 & 43.2 & 30.5 & 0.5 & 92.4 \\
\hline & below $\$ 2 /$ day & & 2002 & 39.1 & 27.2 & 0.2 & 90.7 \\
\hline
\end{tabular}


Panel B: Pair-wise Pearson Correlations of Variables

\begin{tabular}{|c|c|c|c|c|c|c|c|c|c|c|c|}
\hline & & 1 & 2 & 3 & 4 & 5 & 6 & 7 & 8 & 9 & 10 \\
\hline 1 & Growth Rate & 1 & & & & & & & & & \\
\hline 2 & Income & 0.16 & 1 & & & & & & & & \\
\hline 3 & Female Schooling & 0.17 & 0.70 & 1 & & & & & & & \\
\hline 4 & Male Schooling & 0.26 & 0.57 & 0.83 & 1 & & & & & & \\
\hline 5 & PPPI & -0.19 & -0.13 & -0.16 & -0.23 & 1 & & & & & \\
\hline 6 & Billionaire Wealth Inequality & -0.03 & 0.29 & 0.36 & 0.33 & -0.11 & 1 & & & & \\
\hline 7 & $\begin{array}{l}\text { Politically Unconnected } \\
\text { Wealth Inequality }\end{array}$ & -0.04 & 0.24 & 0.32 & 0.25 & -0.09 & 0.89 & 1 & & & \\
\hline 8 & $\begin{array}{l}\text { Politically Connected } \\
\text { Wealth Inequality }\end{array}$ & -0.01 & 0.24 & 0.28 & 0.32 & -0.11 & 0.76 & 0.39 & 1 & & \\
\hline 9 & Income Inequality & -0.22 & -0.14 & -0.01 & -0.28 & 0.24 & 0.03 & 0.07 & -0.03 & 1 & \\
\hline 10 & Headcount Poverty & -0.08 & -0.83 & -0.68 & -0.59 & 0.06 & -0.21 & -0.18 & -0.16 & 0.12 & 1 \\
\hline
\end{tabular}

This table presents summary statistics and Pearson correlation coefficients between the regression variables. Panel A includes the mean, standard deviation, minimum, and maximum. Panel B reports the Pearson correlation coefficients with boldface indicating statistical significance at the $1 \%$ level. Growth Rate is the annual rate of growth in real GDP per capita, averaged over a 5-year period; Income is the log of Real GDP per capita in 2000 constant prices (in international dollar per person); Female Schooling is the average years of secondary schooling in the female population aged 25 and above; Male Schooling is the average years of secondary schooling in the male population aged 25 and above; PPPI is price level of investment, measured as the PPP of investment/ exchange rate relative to the USA; Wealth Inequality is Billionaire wealth, divided by GDP; Politically Unconnected Wealth Inequality is Politically unconnected billionaire wealth, divided by GDP; and Politically Connected Wealth Inequality is Politically connected billionaire wealth, divided by GDP. Income Inequality is the Gini coefficient of any quality level and with either person or household as the unit of analysis. Headcount Poverty is the percentage of the population in households with consumption per capita below $\$ 2 /$ day. 
Table 3: Wealth distribution data from the Davies et al. (2008) data set \& Forbes' list of billionaires

Panel A: Data on wealth share held by the top decile and billionaire wealth/GDP

\begin{tabular}{lcccc}
\hline Country & $\begin{array}{c}\text { Percent of } \\
\text { wealth held by } \\
\text { the top decile }\end{array}$ & $\begin{array}{c}\text { Year that the } \\
\text { wealth statistics } \\
\text { pertains to }\end{array}$ & $\begin{array}{c}\text { Closest year(s) } \\
\text { in the } \\
\text { billionaire list }\end{array}$ & $\begin{array}{c}\text { Billionaire wealth/ GDP } \\
\text { in that year(s) }\end{array}$ \\
\hline Australia & 45 & 2002 & 2002 & $1.36 \%$ \\
Canada & 53 & 1999 & $1996 \& 2002$ & $4.38 \%$ \\
China & 41.4 & 2002 & 2002 & $0.07 \%$ \\
Denmark & 76.4 & 1996 & 1996 & $2.60 \%$ \\
France & 61 & 1994 & 1992 & $1.27 \%$ \\
Germany & 44.4 & 1998 & 1996 & $5.37 \%$ \\
India & 52.9 & $2002-03$ & 2002 & $2.55 \%$ \\
Indonesia & 65.4 & 1997 & 1996 & $11.88 \%$ \\
Ireland & 42.3 & 1987 & 2002 & $1.06 \%$ \\
Italy & 48.5 & 2000 & 2002 & $3.16 \%$ \\
Japan & 39.3 & 1999 & $1996 \& 2002$ & $1.73 \%$ \\
Norway & 50.5 & 2000 & 2002 & $0.67 \%$ \\
Republic of Korea & 43.1 & 1988 & 1987 & $2.05 \%$ \\
Spain & 41.9 & 2002 & 2002 & $2.45 \%$ \\
Sweden & 58.6 & 2002 & 2002 & $15.96 \%$ \\
Switzerland & 71.3 & 1997 & 1996 & $11.93 \%$ \\
United Kingdom & 56 & 2000 & 2002 & $2.01 \%$ \\
United States & 69.8 & 2001 & 2002 & $8.28 \%$ \\
\hline
\end{tabular}

Panel B: Data on Gini coefficient of wealth and billionaire wealth/GDP

\begin{tabular}{lcc}
\hline Country & Measure of Gini coefficient in 2000 & Billionaire wealth/GDP in 2002 \\
\hline Argentina & 0.74 & $1.02 \%$ \\
Australia & 0.622 & $1.36 \%$ \\
Brazil & 0.784 & $2.93 \%$ \\
Canada & 0.688 & $6.18 \%$ \\
China & 0.55 & $0.07 \%$ \\
France & 0.73 & $4.54 \%$ \\
Germany & 0.667 & $10.46 \%$ \\
India & 0.669 & $2.55 \%$ \\
Indonesia & 0.764 & $0.92 \%$ \\
Italy & 0.609 & $3.16 \%$ \\
Japan & 0.547 & $1.51 \%$ \\
Mexico & 0.749 & $4.50 \%$ \\
Netherlands & 0.65 & $2.23 \%$ \\
Republic of Korea & 0.579 & $0.76 \%$ \\
Russia & 0.699 & $4.29 \%$ \\
Spain & 0.57 & $2.45 \%$ \\
Switzerland & 0.803 & $15.63 \%$ \\
Taiwan & 0.655 & $4.74 \%$ \\
Thailand & 0.71 & $1.81 \%$ \\
Turkey & 0.718 & $6.20 \%$ \\
United Kingdom & 0.697 & $2.01 \%$ \\
United States & 0.801 & $8.28 \%$ \\
\hline
\end{tabular}

Data on share of wealth held by the top decile is available for Finland and New Zealand in the UNU-WIDER data set (Table 1, p. 4) but they do not have billionaires in any of the four years of our sample, 1987, 1992, 1996, and 2002 and hence are not included in Panel A of Table 3. Data on Gini coefficient for wealth is available for Bangladesh, Nigeria, Pakistan, and Vietnam in the UNU-WIDER data set (Table 3, pp. 9-10) but they do not have billionaires in any year of the four years of our sample, and hence are not included in Panel B of Table 3. 
Table 4: Relationship between billionaire wealth and its components, normalized by GDP and ICRG Corruption Scores

\begin{tabular}{|c|c|c|c|c|c|c|}
\hline & (1) & (2) & (3) & (4) & (5) & (6) \\
\hline Year(s) Included & 1987 & 1992 & 1996 & 2002 & All & All \\
\hline \multicolumn{7}{|c|}{ Panel A: Dependent variable: Politically connected billionaire wealth, normalized by GDP } \\
\hline \multirow[t]{2}{*}{ ICRG Corruption score } & $0.0364 * *$ & $0.0426 * * *$ & $0.0410 * * *$ & $0.0226^{* *}$ & $0.0347^{* * *}$ & $0.0231^{* * *}$ \\
\hline & $(0.0159)$ & $(0.0136)$ & $(0.0148)$ & $(0.00837)$ & $(0.00645)$ & $(0.00784)$ \\
\hline \multirow[t]{2}{*}{ Constant } & -0.000419 & -0.00155 & 0.00164 & $-0.00461^{*}$ & 0.0000741 & 0.00438 \\
\hline & $(0.00170)$ & $(0.00199)$ & $(0.00538)$ & $(0.00272)$ & $(0.00380)$ & $(0.00370)$ \\
\hline $\mathrm{R}^{2}$ & 0.17 & 0.28 & 0.060 & 0.11 & 0.12 & 0.047 \\
\hline F & 5.212 & 9.786 & 7.665 & 7.309 & 7.972 & \\
\hline \multicolumn{7}{|c|}{ Panel B: Dependent variable: Politically unconnected billionaire wealth, normalized by GDP } \\
\hline \multirow[t]{2}{*}{ ICRG Corruption score } & $-0.0413^{* *}$ & -0.0228 & -0.000 & -0.0638 & $-0.0342^{*}$ & -0.0322 \\
\hline & $(0.0158)$ & $(0.0241)$ & $(0.0544)$ & $(0.0449)$ & $(0.0200)$ & $(0.0202)$ \\
\hline \multirow[t]{2}{*}{ Constant } & $0.0397 * * *$ & $0.0330 * * *$ & $0.0624 * *$ & $0.0825 * * *$ & $0.0377 * * *$ & $0.0313 * * *$ \\
\hline & $(0.0104)$ & $(0.0112)$ & $(0.0252)$ & $(0.0262)$ & $(0.00961)$ & $(0.00835)$ \\
\hline $\mathrm{R}^{2}$ & 0.093 & 0.017 & 0.000 & 0.050 & 0.078 & 0.23 \\
\hline $\mathrm{F}$ & 6.791 & 0.891 & 0.000 & 2.019 & 2.825 & \\
\hline \multicolumn{7}{|c|}{ Panel C: Dependent variable: Billionaire wealth, normalized by GDP } \\
\hline \multirow[t]{2}{*}{ ICRG Corruption score } & -0.00487 & 0.0198 & 0.0409 & -0.0411 & 0.000435 & -0.0106 \\
\hline & $(0.0208)$ & $(0.0290)$ & $(0.0574)$ & $(0.0455)$ & $(0.0214)$ & $(0.0219)$ \\
\hline \multirow[t]{2}{*}{ Constant } & $0.0393 * * *$ & $0.0315^{* * *}$ & $0.0640 * *$ & $0.0779 * * *$ & $0.0378 * * *$ & $0.0368 * * *$ \\
\hline & $(0.0103)$ & $(0.0112)$ & $(0.0254)$ & $(0.0261)$ & $(0.0101)$ & $(0.00929)$ \\
\hline $\mathrm{R}^{2}$ & 0.0012 & 0.013 & 0.0090 & 0.020 & 0.066 & 0.20 \\
\hline $\mathrm{F}$ & 0.0547 & 0.466 & 0.508 & 0.817 & 2.288 & \\
\hline Econometric Technique & OLS & OLS & OLS & OLS & Pooled OLS & $\mathrm{RE}$ \\
\hline Number of observations & 22 & 31 & 37 & 41 & 131 & 131 \\
\hline
\end{tabular}

ICRG Corruption score has been rescaled such that higher values indicate more (rather than less) corruption and so that the index ranges from 0 to 1 .

Period fixed effects are introduced but not reported in columns (5) and (6).

Random Effects specification has been used in column (6) in preference to Fixed Effects specification based on the results of a Hausman test.

Robust standard errors in parentheses; standard errors are clustered by country in columns (5) and (6). * p $<0.10, * * \mathrm{p}<0.05, * * * \mathrm{p}<0.01$. 
Table 5: Correlation between the wheat-sugar ratio developed in Easterly (2007) and wealth inequality and its components

\begin{tabular}{lll}
\hline & Correlation coefficient & $\mathrm{p}$-value \\
\hline Politically connected wealth inequality & $-0.425^{* * *}$ & 0.010 \\
Politically unconnected wealth inequality & 0.118 & 0.486 \\
Wealth inequality & -0.148 & 0.382 \\
\hline
\end{tabular}

LWHEATSUGAR, the "wheat-sugar ratio" is defined by Easterly (2007) as log [(1+share of arable land suitable for wheat) / (1+share of arable land suitable for sugarcane)].

Values of LWHEATSUGAR are drawn from Appendix A of Easterly (2007).

For wealth inequality and its components, GDP has been used for the normalization exercise. The values of wealth inequality (and its components) are calculated only for countries which have billionaires in at least one of the four years of the sample. Given the data availability in Easterly (2007), the correlation coefficients presented in the table are estimated on a sample size of 37 countries.

$* \mathrm{p}<0.10, * * \mathrm{p}<0.05, * * * \mathrm{p}<0.01$. 
Table 6: Impact of wealth inequality and its components, income inequality, and headcount poverty on economic growth

\begin{tabular}{|c|c|c|c|c|c|c|}
\hline & (1) & $(2)$ & $(3)$ & $(4)$ & $(5)$ & (6) \\
\hline Wealth Inequality & $\begin{array}{l}-0.132^{*} \\
(0.0771)\end{array}$ & $\begin{array}{l}-0.547 \\
(0.351)\end{array}$ & $\begin{array}{c}-50.07 * * * \\
(13.27)\end{array}$ & & & \\
\hline $\begin{array}{l}\text { Politically unconnected } \\
\text { wealth inequality }\end{array}$ & & & & $\begin{array}{l}-0.0464 \\
(0.0714)\end{array}$ & $\begin{array}{l}-0.154 \\
(0.301)\end{array}$ & $\begin{array}{l}-48.98 \\
(36.52)\end{array}$ \\
\hline $\begin{array}{l}\text { Politically connected } \\
\text { wealth inequality }\end{array}$ & & & & $\begin{array}{c}-0.331^{* * *} \\
(0.0965)\end{array}$ & $\begin{array}{l}-1.625^{* * * *} \\
(0.536)\end{array}$ & $\begin{array}{c}-51.01^{* *} \\
(22.79)\end{array}$ \\
\hline Income Inequality & $\begin{array}{c}0.000564 \\
(0.000422)\end{array}$ & $\begin{array}{l}0.000763^{*} \\
(0.000455)\end{array}$ & $\begin{array}{c}0.000498 \\
(0.000417)\end{array}$ & $\begin{array}{c}0.000530 \\
(0.000426)\end{array}$ & $\begin{array}{c}0.000753 \\
(0.000456)\end{array}$ & $\begin{array}{c}0.000498 \\
(0.000418)\end{array}$ \\
\hline Headcount Poverty & $\begin{array}{c}0.000301 \\
(0.000296)\end{array}$ & $\begin{array}{c}0.000252 \\
(0.000307)\end{array}$ & $\begin{array}{c}0.000353 \\
(0.000286)\end{array}$ & $\begin{array}{c}0.000298 \\
(0.000298)\end{array}$ & $\begin{array}{c}0.000243 \\
(0.000310)\end{array}$ & $\begin{array}{c}0.000352 \\
(0.000297)\end{array}$ \\
\hline Income & $\begin{array}{c}-0.0836^{* * *} \\
(0.0288)\end{array}$ & $\begin{array}{c}-0.0854 * * * \\
(0.0302)\end{array}$ & $\begin{array}{c}-0.0813^{* * *} \\
(0.0285)\end{array}$ & $\begin{array}{c}-0.0792 * * * \\
(0.0291)\end{array}$ & $\begin{array}{c}-0.0818 * * * \\
(0.0304)\end{array}$ & $\begin{array}{c}-0.0812^{* * * *} \\
(0.0286)\end{array}$ \\
\hline Female Schooling & $\begin{array}{l}0.00580 \\
(0.0225)\end{array}$ & $\begin{array}{l}0.00716 \\
(0.0238)\end{array}$ & $\begin{array}{c}0.0111 \\
(0.0214)\end{array}$ & $\begin{array}{c}0.0129 \\
(0.0215)\end{array}$ & $\begin{array}{c}0.0137 \\
(0.0228)\end{array}$ & $\begin{array}{c}0.0112 \\
(0.0220)\end{array}$ \\
\hline Male Schooling & $\begin{array}{l}0.00301 \\
(0.0227)\end{array}$ & $\begin{array}{l}-0.00155 \\
(0.0240)\end{array}$ & $\begin{array}{l}0.00462 \\
(0.0222)\end{array}$ & $\begin{array}{l}0.00202 \\
(0.0220)\end{array}$ & $\begin{array}{l}-0.00218 \\
(0.0234)\end{array}$ & $\begin{array}{l}0.00459 \\
(0.0221)\end{array}$ \\
\hline Price level of investment & $\begin{array}{c}-0.0807 * * \\
(0.0398)\end{array}$ & $\begin{array}{c}-0.0848 * * \\
(0.0403)\end{array}$ & $\begin{array}{l}-0.0695^{*} \\
(0.0384)\end{array}$ & $\begin{array}{l}-0.0802^{*} \\
(0.0422)\end{array}$ & $\begin{array}{l}-0.0834^{*} \\
(0.0419)\end{array}$ & $\begin{array}{l}-0.0697^{*} \\
(0.0388)\end{array}$ \\
\hline Country On List Dummy & $\begin{array}{l}-0.00382 \\
(0.00853)\end{array}$ & $\begin{array}{l}-0.00467 \\
(0.00867)\end{array}$ & $\begin{array}{l}-0.00420 \\
(0.00749)\end{array}$ & $\begin{array}{l}-0.00567 \\
(0.00849)\end{array}$ & $\begin{array}{l}-0.00606 \\
(0.00864)\end{array}$ & $\begin{array}{l}-0.00428 \\
(0.00878)\end{array}$ \\
\hline Constant & $\begin{array}{l}0.634^{* *} \\
(0.241)\end{array}$ & $\begin{array}{c}0.648^{* *} \\
(0.254)\end{array}$ & $\begin{array}{c}0.610^{* *} \\
(0.239)\end{array}$ & $\begin{array}{c}0.597 * * \\
(0.243)\end{array}$ & $\begin{array}{c}0.616^{* *} \\
(0.255)\end{array}$ & $\begin{array}{c}0.609 * * \\
(0.239)\end{array}$ \\
\hline Number of observations & 160 & 149 & 160 & 160 & 149 & 160 \\
\hline $\mathrm{R}^{2}$ & 0.59 & 0.59 & 0.61 & 0.60 & 0.60 & 0.61 \\
\hline $\mathrm{F}$ & 28.39 & 21.54 & 29.68 & 33.99 & 23.70 & 33.06 \\
\hline
\end{tabular}

Growth Rate is the average annual compounded growth rate over a 5-year period of Gross Domestic Product per capita in constant prices and expressed in national currency (Source: IMF World Economic Outlook Database, 2009); Income is the log of Real GDP per capita in International dollars in 2000 constant prices (Source: PWT v6.2); Female (Male) Schooling is the average years of secondary schooling in the female (male) population aged 25 and above (Source: Barro and Lee, 2001); PPPI is price level of investment, measured as the PPP of investment/ exchange rate relative to the USA (rescaled here by dividing by 1,000 ) (Source: PWT v6.2); Wealth Inequality is Billionaire wealth, divided by GDP (col. (1)), physical capital stock (col. (2)), and population (col. (3)). Politically Unconnected Wealth Inequality is Politically unconnected billionaire wealth, divided by GDP (col. (4)), physical capital stock (col. (5)), and population (col. (6)). Politically Connected Wealth Inequality is Politically connected billionaire wealth, divided by GDP (col. (7)), physical capital stock (col. (8)), and population (col. (9)). Measures of billionaire wealth are based on Forbes' billionaire lists for 1987, 1992, 1996, and 2002 along with author calculations. Country on List Dummy = 1 if a country has billionaires in a given year, 0 otherwise and is also based on author calculations. Columns (2) and (5) are estimated using observations for which the capital to GDP ratio is between 2.58 to 14.43, corresponding to the 5 th and 95 th percentile values of the distribution of capital to GDP.

A list of countries included in this estimation are: Algeria, Bangladesh, Bolivia, Botswana, Brazil, Burundi, Cameroon, Central African Republic, Chile, China, Colombia, Costa Rica, Dominican Republic, Ecuador, Egypt, El Salvador, Fiji, Gambia, Ghana, Guatemala, Haiti, Honduras, Hungary, India, Indonesia, Iran, Jamaica, Jordan, Kenya, Lesotho, Malawi, Malaysia, Mali, Mauritania, Mexico, Mozambique, Nepal, Nicaragua, Niger, Pakistan, Panama, Papua New Guinea, Paraguay, Peru, Philippines, Poland, Rwanda, Senegal, Sierra Leone, South Africa, Sri Lanka, Swaziland, Thailand, Trinidad and Tobago, Tunisia, Turkey, Uganda, Venezuela, and Zambia.

All regressions include country and period fixed effects. Robust standard errors, clustered by country, in parentheses $* \mathrm{p}<0.10, * * \mathrm{p}<0.05, * * * \mathrm{p}<0.01$. 
Table 7: Impact of income inequality and/ or headcount poverty on economic growth, without controlling for measures of wealth inequality

\begin{tabular}{lccc|ccc}
\hline & $(1)$ & $(2)$ & $(3)$ & $(4)$ & $(5)$ & $(6)$ \\
\hline Income Inequality & 0.000579 & & 0.000302 & -0.000175 & & -0.000289 \\
& $(0.000435)$ & & $(0.000399)$ & $(0.000448)$ & & $(0.000317)$ \\
Headcount Poverty & 0.000292 & 0.000377 & & 0.000323 & $0.000277^{* *}$ & \\
& $(0.000306)$ & $(0.000232)$ & & $(0.000220)$ & $(0.000134)$ & -0.00456 \\
Income & $-0.0877^{* * *}$ & $-0.0626^{* * *}$ & $-0.0944^{* * *}$ & 0.00320 & 0.00709 & $(0.00405)$ \\
& $(0.0306)$ & $(0.0169)$ & $(0.0239)$ & $(0.00823)$ & $(0.00467)$ & -0.00610 \\
Female Schooling & -0.00280 & -0.00641 & -0.00401 & -0.00356 & -0.00168 & $(0.00672)$ \\
& $(0.0244)$ & $(0.0203)$ & $(0.0146)$ & $(0.0140)$ & $(0.00864)$ & 0.00976 \\
Male Schooling & 0.00440 & 0.0130 & 0.00663 & $0.0167 *$ & $0.0152^{* *}$ & $(0.00620)$ \\
& $(0.0239)$ & $(0.0149)$ & $(0.0137)$ & $(0.00946)$ & $(0.00704)$ & -0.107 \\
Price level of investment & $-0.0972^{* *}$ & -0.0328 & $-0.0941^{* *}$ & -0.0738 & -0.0519 & $(0.0917)$ \\
& $(0.0369)$ & $(0.0270)$ & $(0.0365)$ & $(0.0997)$ & $(0.0342)$ & $0.0669^{*}$ \\
Constant & $0.672^{* *}$ & $0.477^{* * *}$ & $0.820^{* * *}$ & -0.0311 & $-0.0710^{*}$ & $0.0372)$ \\
& $(0.255)$ & $(0.139)$ & $(0.212)$ & $(0.0677)$ & $(0.0420)$ & $(0.03)$ \\
\hline Econometric Technique & \multicolumn{3}{c}{ Fixed Effects } & & & Random Effects \\
\hline $\mathrm{N}$ & 160 & 258 & 265 & 160 & 258 & 265 \\
$\mathrm{R}^{2}$ & 0.56 & 0.41 & 0.46 & 0.2782 & 0.2202 & 0.1639 \\
\hline
\end{tabular}

The measure of income inequality used is the Gini coefficient of any quality level, ranging from 1 to 4 , that is based on either the person or the household as the unit of analysis. Data on income inequality is drawn from the UNU-WIDER World Income Inequality Database 2004.

All regressions include period fixed effects. Regressions in columns (1) - (3) use country-specific fixed effects, whereas regressions in columns (4) - (6) use random effects.

For complete notes, please refer to Table 6 .

Robust standard errors, clustered by country, in parentheses ${ }^{*} \mathrm{p}<0.10,{ }^{* *} \mathrm{p}<0.05,{ }^{* * *} \mathrm{p}<0.01$. 
Table 8: Impact of Income Inequality and Wealth Inequality on Economic Growth; estimated on same set of countries as in Forbes (2000)

\begin{tabular}{|c|c|c|c|c|}
\hline & (1) & $(2)$ & (3) & (4) \\
\hline \multicolumn{5}{|c|}{ Panel A: Assuming income and wealth inequality to have the same effect during the entire sample period } \\
\hline Income Inequality & 0.000751 & 0.000991 & 0.00102 & 0.000947 \\
\hline & $(0.000886)$ & $(0.000830)$ & $(0.000858)$ & $(0.000840)$ \\
\hline Wealth Inequality & & $-0.154 * * *$ & & \\
\hline (GDP used for normalization) & & $(0.0484)$ & & \\
\hline Wealth Inequality & & & $-0.578^{* * *}$ & \\
\hline (Physical capital used for normalization) & & & $(0.179)$ & \\
\hline Wealth Inequality & & & & $-6.255^{* * *}$ \\
\hline (Population used for normalization) & & & & $(2.061)$ \\
\hline Number of observations & 162 & 162 & 152 & 162 \\
\hline $\mathrm{R}^{2}$ & 0.39 & 0.45 & 0.44 & 0.42 \\
\hline $\mathrm{F}$ & 5.343 & 8.717 & 8.740 & 7.138 \\
\hline \multicolumn{5}{|c|}{ Panel B: Allowing for the effects of inequality to differ between the first and second half of the sample periods } \\
\hline Income Inequality & $\begin{array}{c}0.000419 \\
(0.000894)\end{array}$ & $\begin{array}{c}0.000757 \\
(0.000858)\end{array}$ & $\begin{array}{c}0.000698 \\
(0.000896)\end{array}$ & $\begin{array}{c}0.000630 \\
(0.000847)\end{array}$ \\
\hline $\begin{array}{l}\text { Wealth Inequality } \\
\text { (GDP used for normalization) }\end{array}$ & & $\begin{array}{l}-0.131^{* *} \\
(0.0493)\end{array}$ & & \\
\hline Wealth Inequality & & & $-0.525^{* *}$ & \\
\hline (Physical capital used for normalization) & & & $(0.201)$ & \\
\hline $\begin{array}{l}\text { Wealth Inequality } \\
\text { (Population used for normalization) }\end{array}$ & & & & $\begin{array}{l}-7.771^{* * *} \\
(2.690)\end{array}$ \\
\hline $\begin{array}{l}\text { Income Inequality interacted with "First half } \\
\text { of sample period" dummy }\end{array}$ & $\begin{array}{l}0.000750 * * \\
(0.000327)\end{array}$ & $\begin{array}{c}0.000492 \\
(0.000333)\end{array}$ & $\begin{array}{l}0.000653^{*} \\
(0.000344)\end{array}$ & $\begin{array}{r}0.000742^{* *} \\
(0.000317)\end{array}$ \\
\hline $\begin{array}{l}\text { Wealth Inequality interacted with "First half of sample } \\
\text { period" dummy (GDP used for normalization) }\end{array}$ & & $\begin{array}{c}0.0691 \\
(0.0797)\end{array}$ & & \\
\hline $\begin{array}{l}\text { Wealth Inequality interacted with "First half of sample } \\
\text { period" dummy (Physical capital used for normalization) }\end{array}$ & & & $\begin{array}{l}0.0150 \\
(0.346)\end{array}$ & \\
\hline $\begin{array}{l}\text { Wealth Inequality interacted with "First half of sample } \\
\text { period" dummy (Population used for normalization) }\end{array}$ & & & & $\begin{array}{l}-6.665 \\
(5.169)\end{array}$ \\
\hline "First half of sample period" dummy & $\begin{array}{l}-0.0742 * * * \\
(0.0182)\end{array}$ & $\begin{array}{l}-0.0640 * * * \\
(0.0181)\end{array}$ & $\begin{array}{c}-0.0465 * * * \\
(0.0151)\end{array}$ & $\begin{array}{c}-0.0738 * * * \\
(0.0173)\end{array}$ \\
\hline Number of observations & 162 & 162 & 152 & 162 \\
\hline $\mathrm{R}^{2}$ & 0.41 & 0.46 & 0.46 & 0.46 \\
\hline $\mathrm{F}$ & 4.720 & 9.321 & 9.280 & 6.751 \\
\hline
\end{tabular}

"First half of sample period" dummy is set to 1 for the years 1987-1992 and 1992-1997. The measure of income inequality used is the Gini coefficient of any quality level, based on either the person or household as the unit of analysis. Column (3) is estimated using observations for which the capital to GDP ratio is between 2.58 to 14.43 , corresponding to the 5 th and 95 th percentile values of the distribution of capital to GDP.

This regression is estimated only on the sample of countries included in Forbes(2000): Australia, Bangladesh, Belgium, Brazil, Bulgaria, Canada, Chile, China, Colombia, Costa Rica, Denmark, Dominican Republic, Finland, France, Germany, Greece, Hong Kong, Hungary, India, Indonesia, Ireland, Italy, Japan, Malaysia, Mexico, Netherlands, New Zealand, Norway, Pakistan, Peru, Philippines, Poland, Portugal, Republic of Korea, Singapore, Spain, Sri Lanka, Sweden, Thailand, Trinidad and Tobago, Tunisia, Turkey, United Kingdom, United States, and Venezuela.

All regressions include country and period fixed effects. For complete notes, please refer to Table 6 . Robust standard errors, clustered by country, in parentheses ${ }^{*} \mathrm{p}<0.10,{ }^{*} \mathrm{p}<0.05,{ }^{* * *} \mathrm{p}<0.01$. 


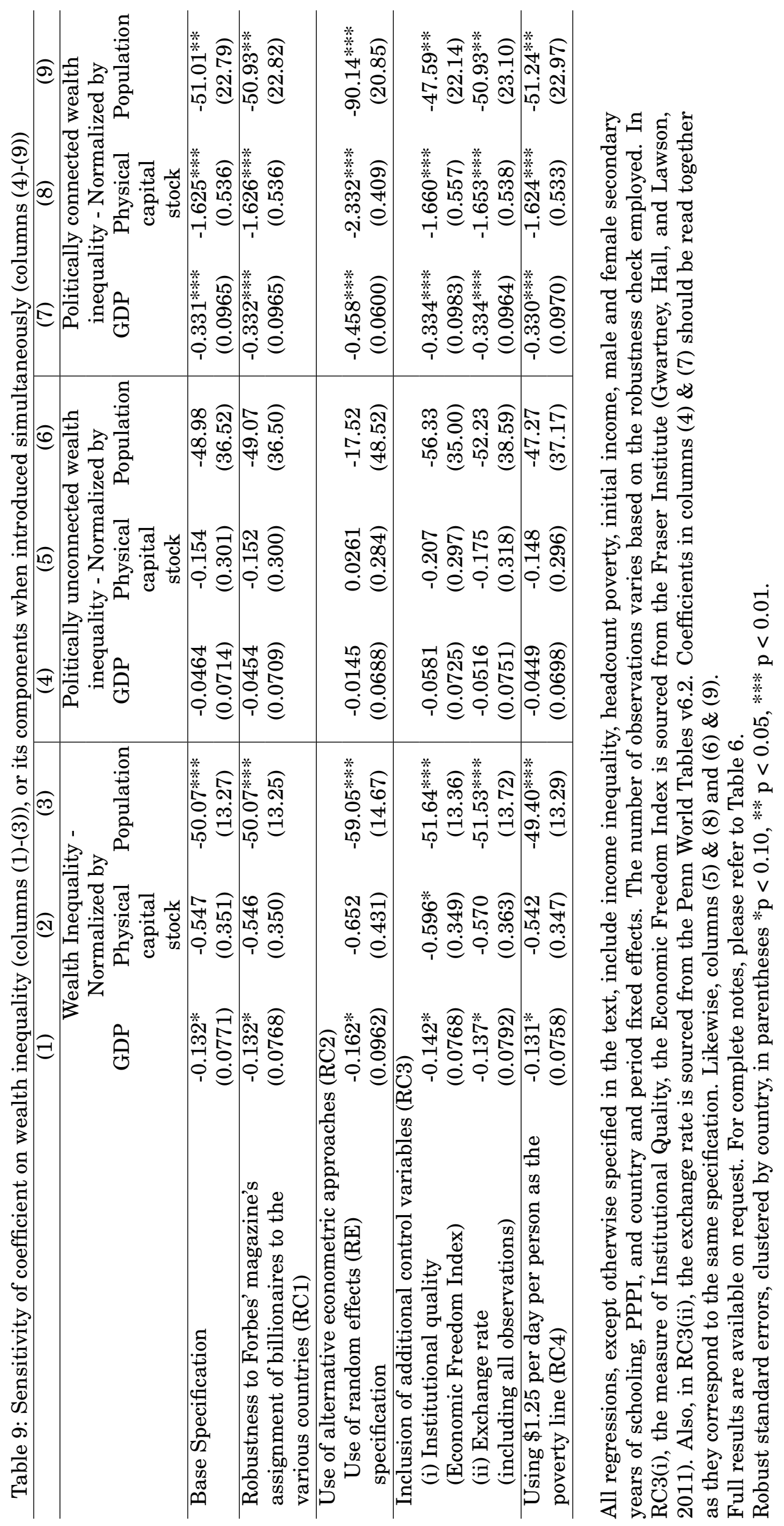


Table A.1: Level of wealth inequality in countries that show up at least once on Forbes' list of billionaires

\begin{tabular}{|c|c|c|c|c|}
\hline Country & 1987 & 1992 & 1996 & 2002 \\
\hline Argentina & - & $1.3 \%$ & $2.5 \%$ & $1.0 \%$ \\
\hline Australia & $1.0 \%$ & $0.7 \%$ & $0.4 \%$ & $1.4 \%$ \\
\hline Bahrain & - & - & $16.4 \%$ & - \\
\hline Belgium & - & - & - & $1.5 \%$ \\
\hline Brazil & $2.0 \%$ & $1.5 \%$ & $2.4 \%$ & $2.9 \%$ \\
\hline Canada & $3.3 \%$ & $2.9 \%$ & $2.6 \%$ & $6.2 \%$ \\
\hline Chile & - & $7.2 \%$ & $11.5 \%$ & $4.3 \%$ \\
\hline China & - & - & - & $0.1 \%$ \\
\hline Colombia & $10.5 \%$ & $7.8 \%$ & $3.9 \%$ & $1.2 \%$ \\
\hline Denmark & - & $1.0 \%$ & $2.6 \%$ & $2.4 \%$ \\
\hline Ecuador & - & - & $5.6 \%$ & - \\
\hline France & $0.4 \%$ & $1.3 \%$ & $2.3 \%$ & $4.5 \%$ \\
\hline Germany & $2.2 \%$ & $4.9 \%$ & $5.4 \%$ & $10.5 \%$ \\
\hline Greece & - & $3.8 \%$ & $9.8 \%$ & $2.3 \%$ \\
\hline Hong Kong & $15.7 \%$ & $20.0 \%$ & $39.9 \%$ & $25.6 \%$ \\
\hline India & $0.4 \%$ & $0.8 \%$ & $0.9 \%$ & $2.5 \%$ \\
\hline Indonesia & $2.3 \%$ & $2.3 \%$ & $11.9 \%$ & $0.9 \%$ \\
\hline Ireland & - & - & - & $1.1 \%$ \\
\hline Israel & - & - & $1.9 \%$ & $5.6 \%$ \\
\hline Italy & $0.9 \%$ & $1.0 \%$ & $1.3 \%$ & $3.2 \%$ \\
\hline Japan & $3.5 \%$ & $2.2 \%$ & $1.9 \%$ & $1.5 \%$ \\
\hline Kuwait & $4.8 \%$ & - & $9.5 \%$ & $14.9 \%$ \\
\hline Malaysia & - & $4.3 \%$ & $25.4 \%$ & $10.0 \%$ \\
\hline Mexico & $0.9 \%$ & $3.8 \%$ & $7.0 \%$ & $4.5 \%$ \\
\hline Netherlands & $2.9 \%$ & $2.0 \%$ & $2.1 \%$ & $2.2 \%$ \\
\hline Norway & - & - & - & $0.7 \%$ \\
\hline Peru & - & - & $1.8 \%$ & - \\
\hline Philippines & - & $2.3 \%$ & $28.2 \%$ & $6.9 \%$ \\
\hline Portugal & - & - & - & $1.3 \%$ \\
\hline Republic of Korea & $2.1 \%$ & $2.7 \%$ & $4.0 \%$ & $0.8 \%$ \\
\hline Russia & - & - & - & $4.3 \%$ \\
\hline Saudi Arabia & $8.2 \%$ & $10.6 \%$ & $12.0 \%$ & $24.6 \%$ \\
\hline Singapore & $6.1 \%$ & $4.8 \%$ & $18.6 \%$ & $13.5 \%$ \\
\hline South Africa & - & - & $2.9 \%$ & $4.0 \%$ \\
\hline Spain & $0.4 \%$ & $0.7 \%$ & $0.7 \%$ & $2.5 \%$ \\
\hline Sweden & $3.5 \%$ & $3.7 \%$ & $4.4 \%$ & $16.0 \%$ \\
\hline Switzerland & $3.1 \%$ & $4.0 \%$ & $11.9 \%$ & $15.6 \%$ \\
\hline Taiwan & $6.7 \%$ & $4.7 \%$ & $8.6 \%$ & $4.7 \%$ \\
\hline Thailand & - & $3.7 \%$ & $11.6 \%$ & $1.8 \%$ \\
\hline Turkey & - & $2.4 \%$ & $3.6 \%$ & $6.2 \%$ \\
\hline United Arab Emirates & - & - & - & $2.4 \%$ \\
\hline United Kingdom & $1.8 \%$ & $1.2 \%$ & $1.3 \%$ & $2.0 \%$ \\
\hline United States & $3.2 \%$ & $3.7 \%$ & $5.7 \%$ & $8.3 \%$ \\
\hline Venezuela & - & $1.7 \%$ & $3.4 \%$ & $10.1 \%$ \\
\hline
\end{tabular}


Table A.2: Rank of countries with the lowest and highest level of politically connected wealth inequality on Transparency International's Corruption Perceptions Index for 1995 and 2012

\begin{tabular}{clcc}
\hline & & $\begin{array}{c}\text { Rank of country in Transparency International's } \\
\text { Corruption Perceptions Index }\end{array}$ \\
\hline Sl. No. & Country & 1995 & 2012 \\
\hline & Total number of countries on the list & 41 & 174 \\
\hline 1. & Hong Kong & 17 & 14 \\
1. & Netherlands & 9 & 9 \\
1. & Singapore & 3 & 5 \\
1. & Sweden & 5 & 4 \\
1. & Switzerland & 8 & 6 \\
1. & United Kingdom & 11 & 17 \\
\hline & Median rank & 9 & 8 \\
& Mean rank & 9 & 9 \\
\hline 37. & Mexico & 32 & 105 \\
38. & Thailand & 34 & 88 \\
39. & Indonesia & 41 & 118 \\
40. & Colombia & 31 & 94 \\
41. & Malaysia & 23 & 54 \\
\hline & Median rank & 32 & 94 \\
& Mean rank & 32 & 92 \\
\hline
\end{tabular}

The countries are ranked from lowest to the highest level of politically connected wealth inequality. The countries that are denoted with a 1. in the first column - Hong Kong, Netherlands, Singapore, Sweden, Switzerland, and United Kingdom appear in every year of the sample and have the lowest level of politically connected wealth inequality. Countries denoted with numbers 37. - 41. in the first column have the highest level of politically connected wealth inequality. Columns 3 and 4 are the ranks of each of countries on the Transparency International's Corruption Perceptions Index for the years 1995 (the first year when the index was constructed) and 2012 (the last year for which the data is available). The first set of median and mean ranks corresponds to the median and mean ranks of Hong Kong, Netherlands, Singapore, Sweden, Switzerland, and United Kingdom on the Corruption Perceptions Index. The last set of median and mean ranks correspond to the median and mean ranks of Mexico, Thailand, Indonesia, Colombia, and Malaysia. 
Figure 1: Decomposing rise in wealth inequality due to a rise in number of billionaires and average wealth per billionaire for France, Germany, and Italy for all four years of sample

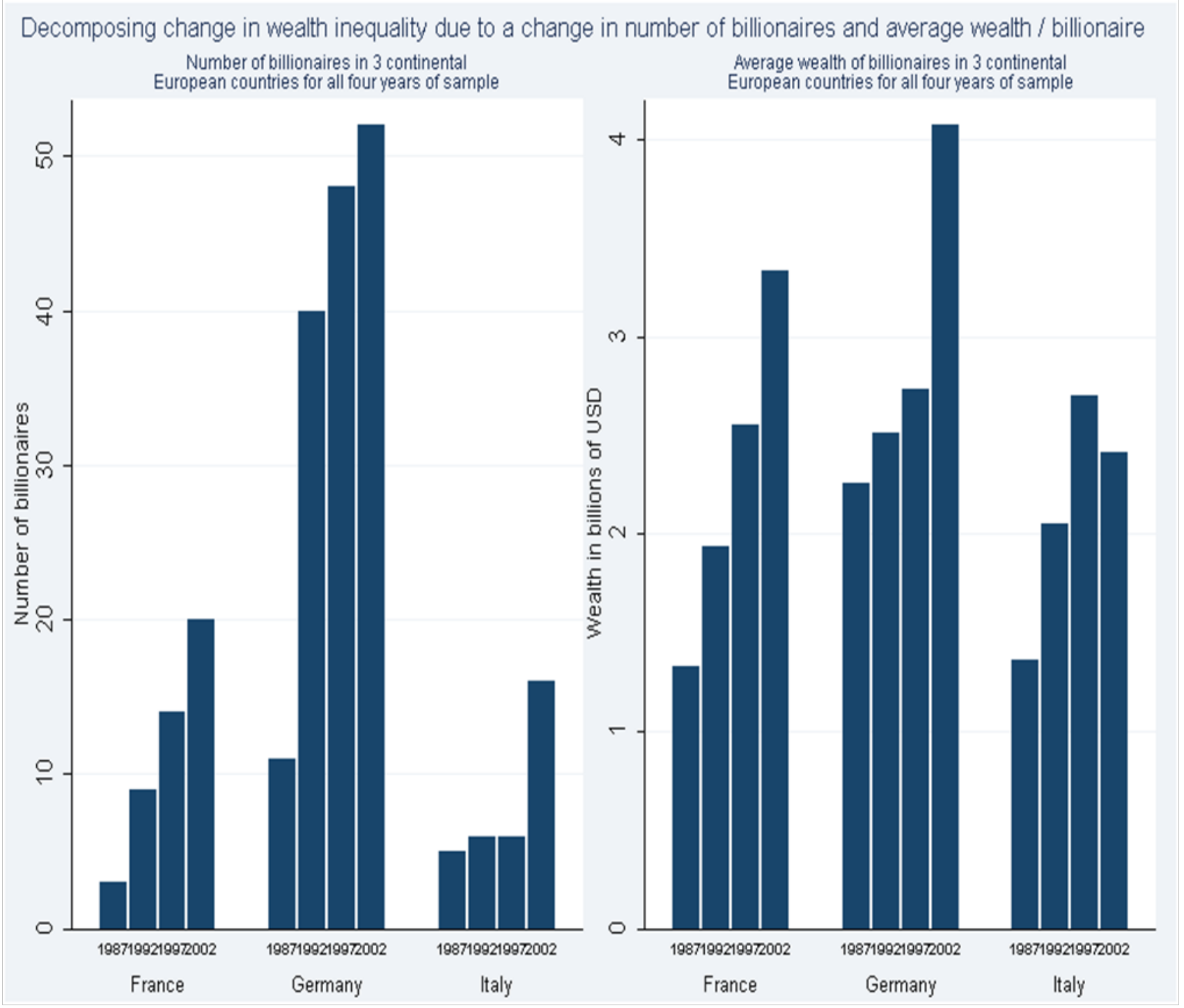

Three countries are chosen to simply make the point that rising wealth inequality is the product of an increase in the number of billionaires and in the average wealth per billionaire. The pattern we see above is generally true of all countries in the sample, including those not captured in the figure. 
Figure 2: Patterns of correlation between components of wealth inequality for 1987, 1992, 1997, and 2002

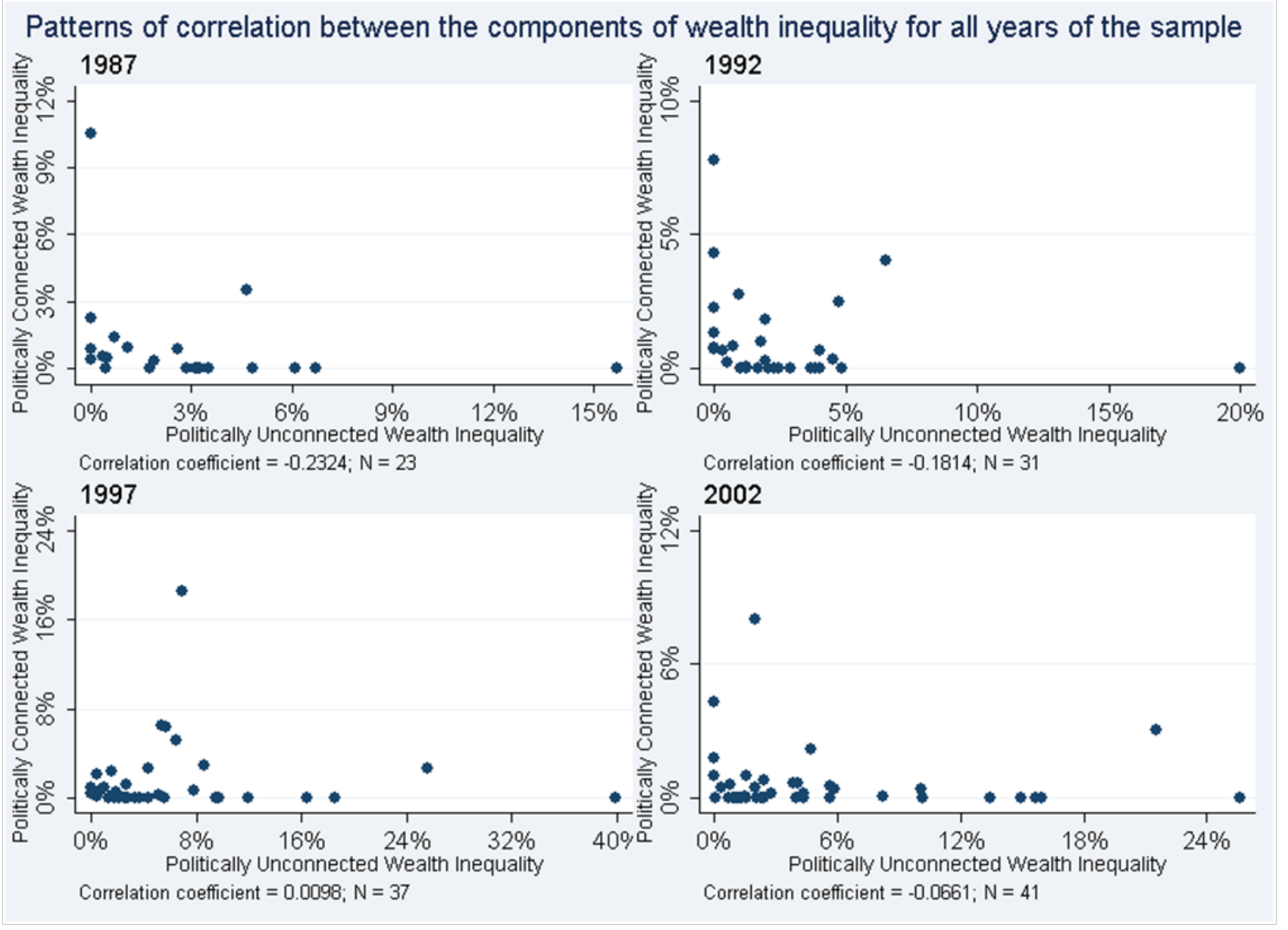

Note: Only countries which have billionaires on the Forbes' list are included in this set of graphs. Politically Unconnected Wealth Inequality is politically unconnected billionaire wealth, divided by GDP and Politically Connected Wealth Inequality is politically connected billionaire wealth, divided by GDP. 